Economics Development Analysis Journal 7 (2) (2018)

\title{
Analisis Faktor-Faktor yang Mempengaruhi Kemiskinan Rumah Tangga (Kasus di Kabupaten Semarang)
}

\section{Erli Widhi Astuti ${ }^{凶}$}

Universitas Diponegoro, Semarang

\begin{tabular}{l} 
Info Artikel \\
\hline Sejarah Artikel: \\
Diterima Januari 2018 \\
Disetujui Maret 2018 \\
Dipublikasikan Mei 2018
\end{tabular}

Keywords:

Households

household members, gen education, employment sector

\begin{abstract}
Abstrak
Permasalahan kemiskinan memang merupakan permasalahan yang kompleks dan bersifat multidimensional. Oleh karena itu, upaya pengentasan kemiskinan harus dilakukan secara komprehensif, mencakup berbagai aspek kehidupan masyarakat dan dilaksanakan secara terpadu. Berbagai program pengentasan kemiskinan telah dilaksanakan, namun penurunan angka kemiskinan tidak signifikan. Tujuan daripenelitian ini adalah menganalisis bagaimana faktor-faktor jumlah anggota rumah tangga, angka ketergantungan (dependency ratio), jenis kelamin kepala rumah tangga, keluhan kesehatan kepala rumah tangga, tingkat pendidikan kepala rumah tangga, sektor lapangan pekerjaan utama kepala rumah tangga mempengaruhi kemiskinan rumah tangga di Kabupaten Semarang. Penelitian ini menggunakan data Survei Sosial Ekonomi Nasional (Susenas) di Kabupaten Semarang Tahun 2013 yang diperoleh dari data Badan Pusat Statistik (BPS).Jumlah sampelsebanyak 791 rumah tangga.Penelitian ini menggunakan metode analisis regresi logistik yang diolah dengan program SPSS 16.0.
\end{abstract}

\begin{abstract}
The problem of poverty is a complex problem and multidimensional. Therefore, the fight against poverty must be comprehensive, covering various aspects of community life and implemented in an integrated manner. The purpose of this study is to analyze how the factors of the number of household members, the rate of dependence (dependency ratio), gender of household head, health complaints of household head, level of education of household head, sector of employment major household head affect household poverty stairs in Semarang Regency. This study uses data of the National Socioeconomic Survey (Susenas) in Semarang District in 2013 were obtained from the Central Statistics Agency (BPS). The total sample of 791 households. This research used logistic regression analyzes were processed with SPSS 16.0. The results showed that the variable Number of Household Members, Figures Addiction, Education Level of Household Head, Public Sector Head of Household significantly affect household poverty in Semarang regency. These variables were affected positively. While Household Head Gender variable and Health Complaint of Household Head does not significantly affect household poverty at the level of five percent, but significant at the 15 percent level. These variables affected negatively.
\end{abstract}

J1. Prof H. Soedarto, S.H., Tembalang, Semarang, Jawa Tengah, Indonesia

E-mail: erlie_semarang@yahoo.com 


\section{PENDAHULUAN}

Permasalahan kemiskinanmerupakan permasalahan yang kompleks dan bersifat multidimensional. Oleh karena itu, upaya pengentasan kemiskinan harus dilakukan secara komprehensif, mencakup berbagai aspek kehidupan masyarakat dan dilaksanakan secara terpadu (Nasir, dkk, 2008).

Berbagai upayapenanggulangan kemiskinan yang telah diambil pemerintah berfokus pada: peningkatan pertumbuhan ekonomi yang berkualitas melalui upaya padat karya, perdagangan ekspor serta pengembangan UMKM,peningkatan akses terhadap kebutuhan dasar seperti pendidikan dan kesehatan, pemberdayaan masyarakat lewat Program Nasional Pemberdayaan Masyarakat (PNPM) yang bertujuan untuk membuka kesempatan berpartisipasi bagi masyarakat miskin dalam proses pembangunan dan meningkatkan peluang dan posisi tawar masyarakat miskin, serta perbaikan sistem bantuan dan jaminan sosial lewat Program Keluarga Harapan (PKH) (Suryawati, 2005). Berdasarkan rencana aksi penanggulangan kemiskinan di Jawa Tengah, dicanangkan 4 strategi yaitu: mengurangi beban pengeluaran masyarakat miskin, yang diupayakan melalui pemenuhan jaminan perlindungan sosial, meningkatan kemampuan dan pendapatan masyarakat miskin dengan pemberdayaan ekonomi, mengembangkan dan menjamin keberlanjutan usaha mikro dan kecil melalui pengembangan ekonomi berbasis UMKM, sinergitas kebijakan dan program penanggulangan kemiskinan dengan optimalisasi program atau anggaran, baik APBN, APBD provinsi, APBD kabupaten/kota, corporate social responsibility (CSR) perusahaan, maupun swadaya masyarakat. (Heru Sudjatmiko, 2016)

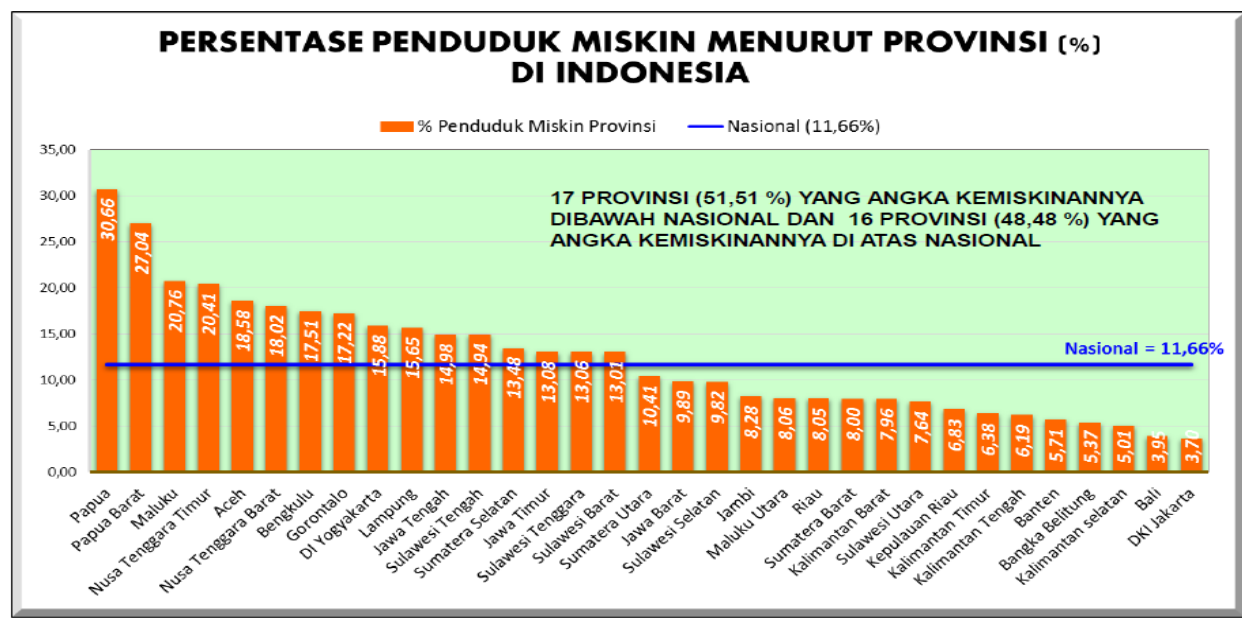

Gambar 1. Persentase Penduduk Miskin Menurut Provinsi (\%) di Indonesia

Sumber: BPS, Tahun 2012

Provinsi Jawa Tengah merupakan salah satu provinsi yang mempunyai tingkat kemiskinan tinggi di Indonesia. Pada tahun 2012 posisi kemiskinan Jawa Tengah (14,98\%) berada di atas tingkat kemiskinan nasional yaitu sebesar $11,66 \%$. Hal ini mengindikasikan bahwa Jawa Tengah merupakan provinsi yang mempunyai tingkat kemiskinan cukup parah. Apalagi jika dibandingkan dengan provinsi tetangga yaitu Jawa Timur (13,08\%) dan Jawa Barat (9,89\%)

yang mempunyai persentase kemiskinan di bawah Jawa Tengah. Jika dilihat dari Gambar 1.2 perkembangan kemiskinan, Jawa Tengah memiliki tren tingkat kemiskinan yang menurun dari tahun ke tahun. Hal ini bisa tercermin dari persentase penduduk miskin tahun 2010 sebesar $16,56 \%$ berubah menjadi $13,58 \%$ di tahun 2014 . 
Akan tetapi harus ada keberlanjutan dalam agar tingkat kemiskinannya menyentuh angka menurunkan tingkat kemiskinan di Jawa Tengah satu digit saja.

Tabel 1.Penduduk Miskin Menurut Kabupaten/Kota di Jawa Tengah Tahun 2010 - 2014

\begin{tabular}{|c|c|c|c|c|c|c|c|c|c|c|}
\hline \multirow{2}{*}{ Kabupaten/Kota } & \multicolumn{4}{|c|}{ Jumlah Penduduk Miskin (000 org) } & \multicolumn{6}{|c|}{ Persentase Penduduk Miskin } \\
\hline & 2010 & 2011 & 2012 & 2013 & 2014 & 2010 & 2011 & 2012 & 2013 & 2014 \\
\hline Cilacap & 297.2 & 282.0 & 260.9 & 255.7 & 239.8 & 18.11 & 17.15 & 15.92 & 15.24 & 14.21 \\
\hline Banyumas & 314.1 & 328.5 & 303.9 & 296.8 & 283.5 & 20.20 & 21.11 & 19.44 & 18.44 & 17.45 \\
\hline Purba & 208.9 & 196.0 & 181.3 & 31.1 & 176.0 & 24.58 & 23.06 & 21.19 & 20.53 & 19.75 \\
\hline Banjarnegara & 166.7 & 177.3 & 164.0 & 166.8 & 159.5 & 19.17 & 20.38 & 18.87 & 18.71 & 17.77 \\
\hline Kebu & 263.0 & 279.4 & 258.5 & 251.1 & 242.3 & 22.71 & 24.06 & 22.40 & 21.32 & 20.50 \\
\hline Purworejo & 115.3 & 121.9 & 112.8 & 109.0 & 102.1 & 16.61 & 17.51 & 16.32 & 15.44 & 14.41 \\
\hline & 174.7 & 183.0 & 169.3 & 170.1 & 165.8 & 23.16 & 24.21 & 22.50 & 22.08 & 21.42 \\
\hline Mage & 167.2 & 179.6 & 166.2 & 171.0 & 160.5 & 14.14 & 15.18 & 13.97 & 13.96 & 12.98 \\
\hline Boyolali & 127.8 & 139.5 & 129.1 & 126.5 & 118.6 & 13.72 & 14.97 & 13.88 & 13.27 & 12.36 \\
\hline Klaten & 197.4 & 203.1 & 187.9 & 179.5 & 168.2 & 17.47 & 17.95 & 16.71 & 15.60 & 14.56 \\
\hline & 90.2 & 92.0 & 85.1 & 84.1 & 78.9 & 10.94 & 11.13 & 10.16 & 9.87 & 9.18 \\
\hline Wonogiri & 145.5 & 146.4 & 135.4 & 132.2 & 123.9 & 15.68 & 15.74 & 14.67 & 14.02 & 13.09 \\
\hline Kara & 113.8 & 124.5 & 115.2 & 114.4 & 107.3 & 13.98 & 15.29 & 14.07 & 13.58 & 12.62 \\
\hline Srag & 149.7 & 154.3 & 142.8 & 39.0 & 130.3 & 17.49 & 17.95 & 16.72 & 15.93 & 14.87 \\
\hline Grob & 233.7 & 227.8 & 210.8 & 199.0 & 186.5 & 17.86 & 17.38 & 16.14 & 14.87 & 13.86 \\
\hline Blora & 134.9 & 134.9 & 124.8 & 123.8 & 116.0 & 16.27 & 16.24 & 15.11 & 14.64 & 13.66 \\
\hline Rem & 138.5 & 140.4 & 129.9 & 128.0 & 120.0 & 23.41 & 23.71 & 21.88 & 20.97 & 19.50 \\
\hline Pati & 172.4 & 175.1 & 162.0 & 157.9 & 148.1 & 14.48 & 14.69 & 13.61 & 12.94 & 12.06 \\
\hline Kud & 70.2 & 73.6 & 68.1 & 70.1 & 65.8 & 9.02 & 9.45 & 8.63 & 8.62 & 7.99 \\
\hline Jep & 111.8 & 113.3 & 104.8 & 106.9 & 100.5 & 10.18 & 10.32 & 9.38 & 9.23 & 8.55 \\
\hline Dem & 198.8 & 192.5 & 178.1 & 172.5 & 162.0 & 18.76 & 18.21 & 16.73 & 15.72 & 14.60 \\
\hline Sema & 97.9 & 96.0 & 88.8 & 83.2 & 79.8 & 10.50 & 10.30 & 9.40 & 8.51 & 8.05 \\
\hline Tem & 95.3 & 94.9 & 87.8 & 91.1 & 85.5 & 13.46 & 13.38 & 12.32 & 12.42 & 11.55 \\
\hline Kendal & 130.4 & 128.6 & 119.0 & 117.7 & 110.5 & 14.47 & 14.26 & 13.17 & 12.68 & 11.80 \\
\hline Batang & 103.6 & 95.3 & 88.2 & 87.5 & 82.1 & 14.67 & 13.47 & 12.40 & 11.96 & 11.13 \\
\hline Pekalc & 136.6 & 125.9 & 116.5 & 116.5 & 109.3 & 16.29 & 15.00 & 13.86 & 13.51 & 12.57 \\
\hline Pemala & 251.8 & 261.2 & 241.7 & 246.8 & 237.0 & 19.96 & 20.68 & 19.28 & 19.27 & 18.44 \\
\hline Tegal & 182.5 & 161.1 & 149.0 & 149.8 & 140.3 & 13.11 & 11.54 & 10.75 & 10.58 & 9.87 \\
\hline Brebes & 398.7 & 394.4 & 364.9 & 367.9 & 355.1 & 23.01 & 22.72 & 21.12 & 20.82 & 20.00 \\
\hline Kota & 12.4 & 13.1 & 12.1 & 11.8 & 11.0 & 10.51 & 11.06 & 10.31 & 9.80 & 9.14 \\
\hline Kota Surakarta & 69.8 & 64.5 & 59.7 & 59.7 & 55.9 & 13.96 & 12.90 & 12.01 & 11.74 & 10.95 \\
\hline Kota Salatiga & 14.2 & 13.3 & 12.3 & 11.5 & 10.8 & 8.28 & 7.80 & 7.11 & 6.40 & 5.93 \\
\hline Kota Semara & 79.7 & 88.5 & 81.9 & 86.7 & 84.7 & 5.12 & 5.68 & 5.13 & 5.25 & 5.04 \\
\hline Kota I & 26.4 & 28.3 & 26.8 & 24.1 & 23.6 & 9.37 & 10.04 & 9.47 & 8.26 & 8.02 \\
\hline Kota Tegal & 25.7 & 25.9 & 24.0 & 21.6 & 20.9 & 10.62 & 10.81 & 10.04 & 8.84 & 8.54 \\
\hline Jawa Tengah & $5,217.2$ & $5,256.0$ & $4,863.4$ & $4,811.3$ & $4,561.8$ & 16.11 & 16.21 & 14.98 & 14.44 & 13.58 \\
\hline
\end{tabular}

Sumber : BPS Provinsi Jawa Tengah, 2015 


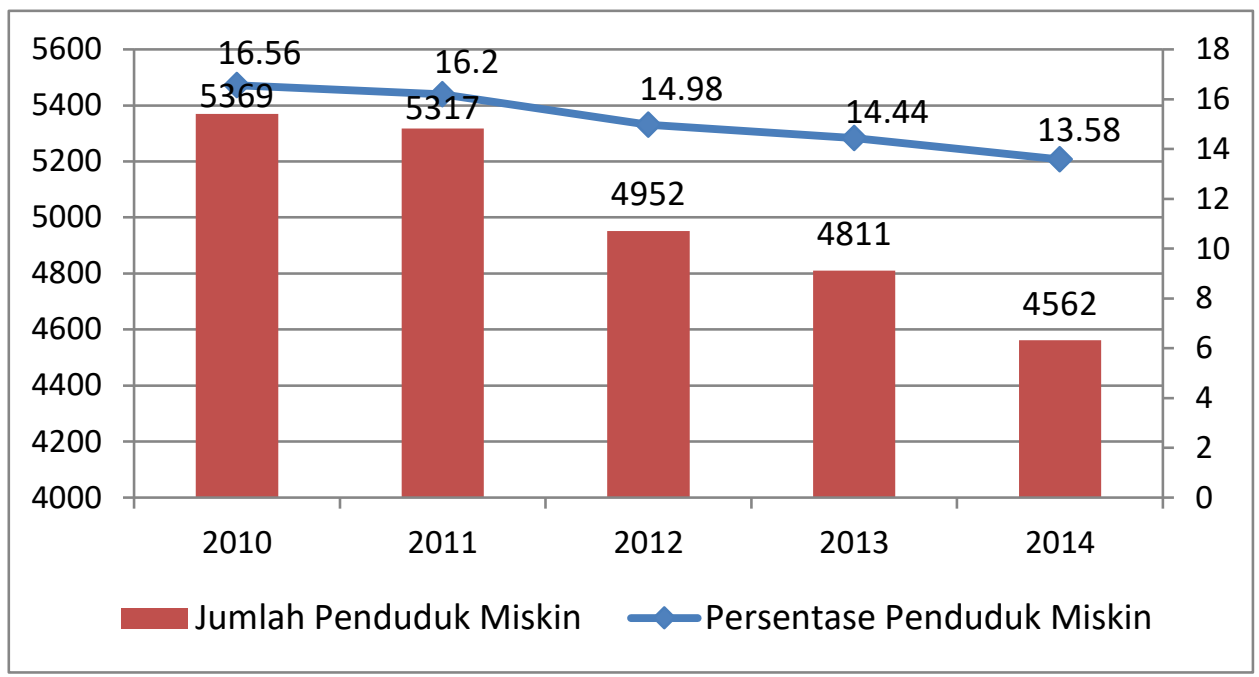

Gambar 2. Jumlah dan Persentase Penduduk Miskin Provinsi Jawa Tengah

Tahun $2010-2014$

Sumber : BPS, 2015

Provinsi Jawa Tengah yang mempunyai 35 kabupten/kota memiliki tingkat kemiskinan yang beragam mulai dari yang terendah sekitar5\% dan yang tertinggi mencapai lebih dari 20\%. Pada tahun 2014 daerah yang mempunyai tingkat kemiskinan terendah yaitu Kota Semarang sebesar 5,04\% dan daerah yang memiliki tingkat kemiskinan terbesar yaitu Kabupaten Wonosobo sebesar 21,42\%. Kabupaten Semarang secara geografis berbatasan langsung dengan Kota Semarang yang merupakan ibukota Provinsi Jawa Tengah dan merupakan salah satu daerah penyangga ibukota provinsi. Kabupaten Semarang dengan slogannya Intanpari (industri, pertanian, pariwisata) mempunyai tingkat kemiskinan yang relatif rendah dibanding dengan kabupaten/kota di Provinsi Jawa Tengah. Dengan persentase maupun jumlah penduduk miskin yang terus menurun dalam kurun waktu lima tahun terakhir, yaitu dari 10,50 persen menjadi 8,05 persen atau dari 97,9 ribu jiwa menjadi 79,8 ribu jiwa.

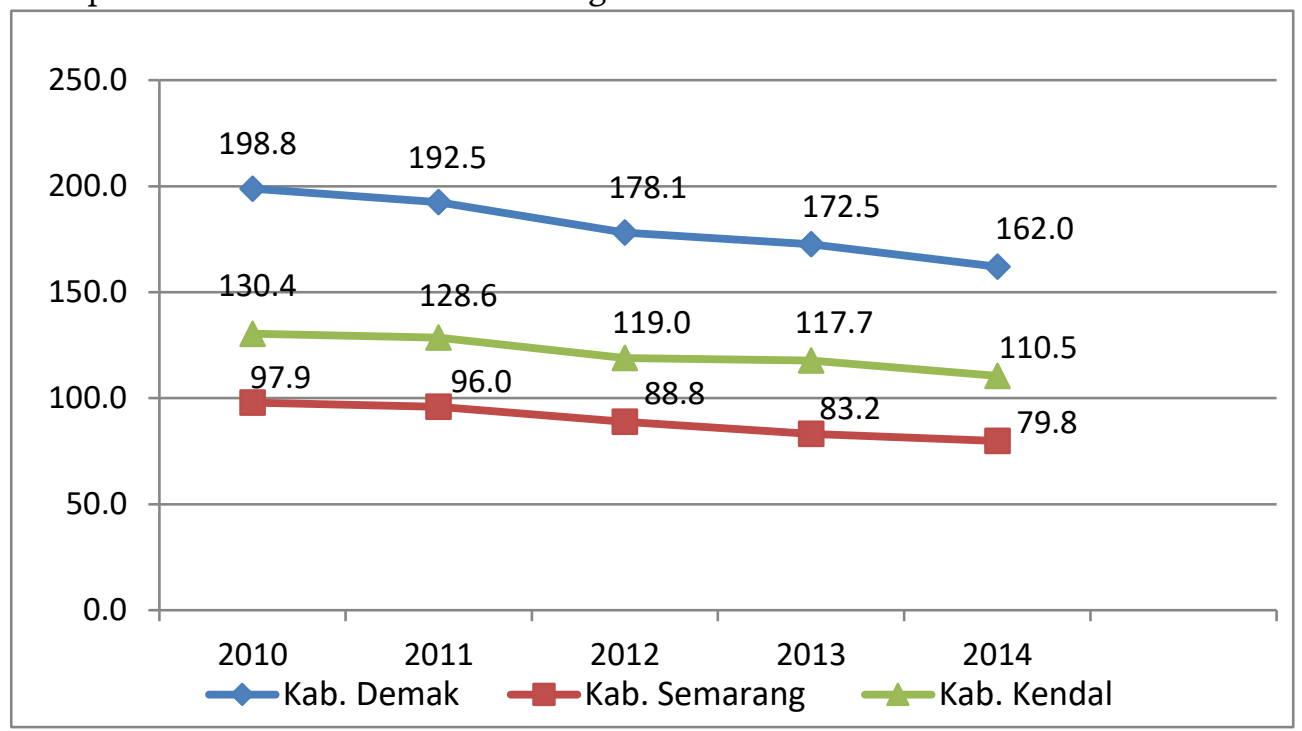

Gambar 3. Jumlah dan Persentase Penduduk Miskin Provinsi Jawa Tengah

Tahun 2010 - 2014

Sumber : BPS, 2015 
Berbagai program pengentasan kemiskinan telah diluncurkan namun penuruan angka kemiskinan di Kabupaten Semarang relatif kecil dibandingkan dengan kabupaten yang ada di sekitar ibukota provinsi lainnya yaitu Kabupaten Kendal dan Demak..Apakah program-program pengentasan kemiskinan yang ada selama ini belum menyentuh akar permasalahan? Faktor-faktor apa saja yang mempengaruhi kemiskinan rumah tangga di Kabupaten Semarang?Apakah jumlah anggota rumah tangga, angka ketergantungan, jenis kelamin kepala rumah tangga, keluhan kesehatan kepala rumah tangga, tingkat pendidikan kepala rumah tangga dan sektor lapangan pekerjaan utama kepala rumah tangga mempengaruhi kemiskinan rumahtangga di Kabupaten Semarang?

Kemiskinan menurut World Bank Institute (2002) didefinisikan sebagai apakah rumah tangga atau individu memiliki sumberdaya atau kemampuan yang cukup untuk memenuhi kebutuhannya.

Menurut Sayogyo (dalam Cess, 2003), kemiskinan absolut diukur dengan menghitung jumlah penduduk yang memiliki pendapatan per kapita yang tidak mencukupi untuk mengkonsumsi barang dan jasa yang nilainya ekuivalen dengan 320 kilogram beras per kapita per tahun untuk perdesaan dan 480 kilogram untuk perkotaan. Sementara Sen (dalam BPS, 2004) menyatakan bahwa kemiskinan adalah "the failure to have certain minimum capabilities". Definisi ini juga mengacu pada standar kemampuan minimum tertentu, berarti penduduk yang tidak mampu melebihi kemampuan minimum tersebut dikatagorikan miskin.

Dalam penelitian ini teori kemiskinan yang digunakan adalah konsep kemiskinan yang digunakan oleh Badan Pusat Statistik (BPS),dimana konsep kemiskinan didekati dengan ukuran kemiskinan makro Penghitungan penduduk miskin menurut ukuran makro ditentukan berdasarkan pendekatan kebutuhan dasar (basic need approach). Penduduk disebut miskin apabila penduduk tersebut di bawah batas miskin atau garis kemiskinan. Garis kemiskinan adalah nilai rupiah yang dikeluarkan seseorang dalam memenuhi kebutuhan hidup minimum, baik makanan maupun non makanan. Garis kemiskinan makanan mengacu pada pengeluaran seseorang untuk memenuhi kebutuhan minimum makanannya sebanyak 2.100 kilo kalori per kapita per hari, dan garis kemiskinan non makanan mengacu kepada pengeluaran seseorang untuk dapat memenuhi kebutuhan minimum bukan makanan.

Dalam analisis kemiskinan beberapa ukuran/indeks seperti yang direkomendasikan oleh World Bank Institute (2002) antara lain Headcount Index, Poverty Gap Index, Poverty Severity Index, dan waktu yang dibutuhkan untuk keluar dari kemiskinan yang dapat dijelaskan sebagai berikut:

Indeks Kemiskinan (Headcount Index/HI), Indeks kemiskinan merupakan ukuran yang paling luas digunakan karena sangat sederhana, yaitu mengukur proporsi penduduk yang dikategorikan sebagai miskin, sering dinotasikan dengan $\mathrm{P}_{\mathrm{o}}$.

Indeks Kesenjangan Kemiskinan (Poverty Gap Index/PGI), Indeks Kesenjangan Kemiskinan menghitung seberapa jauh individu jatuh di bawah garis kemiskinan. Ukuran ini merupakan ukuran rata-rata kesenjangan pengeluaran/pendapatan masing-masing penduduk miskin terhadap garis kemiskinan (penduduk tidak miskin mempunyai gap bernilai $0)$.

Indeks Keparahan Kemiskinan (Poverty Severity Index/PSI), ukuran ini secara sederhana merupakan jumlah dari kesenjangan kemiskinan tertimbang (sebagai proporsi garis kemiskinan), dimana penimbangnya adalah sebanding dengan kesenjangan kemiskinan itu sendiri. Misalkan jika kesenjangan kemiskinan sebesar 10 persen dari garis kemiskinan diberikan penimbang 10 persen dan jika kesenjangan kemiskinan sebesar 50 persen diberikan penimbang 50 persen.

Dalam analisis kebijakan penurunan kemiskinan, informasi tentang perkiraan waktu yang dibutuhkan untuk keluar dari kemiskinan sangat penting. Formula statistik yang berkenaan dengan hal ini dirumuskan oleh Morduch (1998, dalam World Bank Institute, 2002); statistik ini 
dapat didekomposisikan menurut sub-kelompok penduduk dan juga sensitif secara distribusi. Untuk orang ke-j $\left(\mathrm{x}_{\mathrm{j}}\right)$ di bawah garis kemiskinan (z), waktu yang diharapkan untuk keluar (melewati) dari kemiskinan, jika konsumsi per kapita tumbuh secara positif pada tingkat g per tahun adalah:

$$
t_{g}^{j}=\frac{\ln (z)-\ln \left(x_{j}\right)}{g}
$$

Analisis kemiskinan tidak terlepas dari analisis tingkat kesejahteraan. Salah satu pendekatan untuk mengukur kesejahteraan ekonomi adalah berdasarkan pengeluaran konsumsi atau pendapatan.

World Bank Institute (2002) menjelaskan bahwa dalam menganalisis kemiskinan menggunakan pendekatan konsumsi rumah tangga atau pengeluaran per kapita, dan fungsi pengeluaran akan memfasilitasi analisis yang sederhana. Dalam bentuk yang sederhana, fungsi pengeluaran menunjukkan biaya yang diperlukan untuk memenuhi tingkat utilitas tertentu, yang diturunkan dari sebuah vektor barang-barang komoditas tertentu dengan harga tertentu. Misalkan ukuran konsumsi bagi rumah tangga i dinyatakan dengan yi, maka ukuran pengeluaran dari kesejahteraan dapat dinyatakan dengan:

yi $=p \cdot q=e(p, x, u)$

dimana $\mathrm{p}$ adalah vektor harga barangbarang komoditas dan jasa; q adalah vektor kuantitas barang-barang komoditas dan jasa yang dikonsumsi; e(.) adalah fungsi pengeluaran; $\mathrm{x}$ adalah vektor karakteristik rumah tangga (misalnya jumlah orang dewasa, jumlah anak, dan sebagainya); dan $\mathrm{u}$ adalah tingkat utilitas atau kesejahteraan yang dicapai rumah tangga. Dengan kata lain untuk harga $p$ tertentu yang dialami rumah tangga, dan karakteristik demografinya (x), yi mengukur pengeluaran yang dibutuhkan untuk mencapai tingkat utilitas u.

Dalam menganalisis determinan kemiskinan, lebih lanjut dijelaskan teknik regresi semilog yang didefinisikan sebagai:

$\log w i=\gamma \mathrm{Xi}+\varepsilon i$, dimana wi adalah pengeluaran per kapita rumah tangga dibagi dengan nilai garis kemiskinan; Xi adalah vektor variabel bebas (karakteristik demografi) dan ei adalah kesalahan (error). Namun beberapa peneliti lebih suka menggunakan bentuk variabel biner (dua kategori) pada sisi kiri (variabel tak bebas) persamaan tersebut World Bank Institute (2002).

Kemiskinan disamping disebabkan oleh faktor ekonomi, juga dapat diakibatkan oleh faktor-faktor nonekonomi seperti rendahnya pendidikan dan buruknya kondisi kesehatan masyarakat. Namun secara umum penyebab kemiskinan dapat dilihat dari tiga bentuk, yaitu: Kemiskinan struktural, yaitu kemiskinan yang disebabkan oleh hal-hal yang berhubungan dengan kebijakan, peraturan maupun lembaga yang ada di masyarakat sehingga dapat menghambat peningkatan produktivitas dan mobilitas masyarakat; 2) Kemiskinan kultural, yaitu kemiskinan yang berhubungan dengan adanya nilai-nilai yang tidak produktif dalam masyarakat, tingkat pendidikan yang rendah, kondisi kesehatan dan gizi yang buruk; dan

Kemiskinan alamiah, yaitu kemiskinan yang ditunjukkan oleh kondisi alam maupun geografis yang tidak mendukung, misalnya daerah tandus, kering, maupun keterisolasian daerah (Makmun, 2003)

Sahdan (2005) menyebutkan variabelvariabel penyebab kemiskinan antara lain pendidikan yang rendah, rendahnya mutu kesehatan masyarakat, kepemilikan alat-alat produktif yang terbatas, rendahnya penguasaan teknologi dan kurangnya keterampilan, faktor kultur dan struktural. Dalam analisis lebih lanjut disebutkan bahwa indikator utama kemiskinan adalah; (1) terbatasnya kecukupan dan mutu pangan; (2) terbatasnya akses dan rendahnya mutu layanan kesehatan; (3) terbatasnya akses dan rendahnya mutu layanan pendidikan; (4) terbatasnya kesempatan kerja dan berusaha; (5) lemahnya perlindungan terhadap aset usaha, dan perbedaan upah; (6) terbatasnya akses layanan perumahan dan sanitasi; (7) terbatasnya akses terhadap air bersih; (8) lemahnya kepastian kepemilikan dan penguasaan tanah; (9) memburuknya kondisi lingkungan hidup dan 
sumberdaya alam, serta terbatasnya akses masyarakat terhadap sumber daya alam; (10) lemahnya jaminan rasa aman; (11) lemahnya partisipasi; (12) besarnya beban kependudukan yang disebabkan oleh besarnya tanggungan keluarga; (13) tata kelola pemerintahan yang buruk yang menyebabkan inefisiensi dan inefektivitas dalam pelayanan publik, meluasnya korupsi dan rendahnya jaminan sosial terhadap masyarakat.

World Bank Institute (2002) menjelaskan bahwa faktor-faktor penyebab kemiskinan dapat berupa karakteriktik penduduk menurut wilayah, komunitas, karakteristik rumah tangga dan karakteristik individu. Karakteristik wilayah atau komunitas didekati dengan kondisi tempat tinggal di daerah perkotaan/perdesaan. Sedangkan karakteristik rumah tangga dan individu antara lain dapat dilihat dari karakteristik demografi (yaitu struktur dan ukuran rumah tangga, rasio ketergantungan dan jender kepala rumah tangga); karakteristik ekonomi (yaitu ketenagakerjaan, pendapatan, struktur pengeluaran, dan kepemilikan rumah tangga); dan karakteristik sosial (yaitu kesehatan, pendidikan, dan tempat tinggal/perumahan).

Studi kasus oleh Hentschel, dkk (2000) di Ekuador mengidentifikasikan bahwa yang mempengaruhi konsumsi rumah tangga antara lain ukuran rumah tangga dan komposisi umur atau jenis kelamin; informasi pendidikan; data kualitas rumah (bahan-bahan, ukuran); akses ke pelayanan publik seperti listrik dan air; bahasa sehari-hari di rumah; dan lokasi tempat tinggal. Mereka menggunakan teknik regresi, dimana variabel tak bebas adalah logaritma dari konsumsi pengeluaran per kapita (yi) dan variabel bebasnya adalah variabel demografi yang diperoleh dari survei (X'), dan dinotasikan sebagai:

$\operatorname{Ln} y i=\square \beta X^{\prime}+\varepsilon i$

Teknik regresi tersebut dikenakan untuk daerah perdesaan dan daerah perkotaan. Kemudian dalam analisis lebih lanjut mereka membandingkan konsumsi per kapita (yi) dengan garis kemiskinan (zi), sehingga diperoleh variabel baru (misal $\mathrm{Pi}$ ) yaitu indikator kemiskinan yang bernilai satu untuk rumah tangga miskin (bila ln yi < ln zi) dan nol untuk yang lain. Pendekatan serupa juga dilakukan oleh beberapa peneliti antara lain Alderman (2001), Minot (2002), Elbers (2004), dan Mathiassen(2007).

Mathiassen (2007) mengidentifikasi indikator kemiskinan dari survei pengeluaran rumah tangga, antara lain angka buta huruf, pendidikan tertinggi yang ditamatkan, sektor pekerjaan utama kepala rumah tangga, kepemilikan aset rumah tangga (barang-barang yang bernilai mahal, kendaraan, alat komunikasi, dll), kondisi perumahan, komposisi demografi (jumlah anggota rumah tangga, angka ketergantungan, umur dan jenis kelamin kepala rumah tangga, jumlah anak di bawah 15 tahun).

Samijan (2004) berdasarkan penelitiannya di Provinsi Papua menyimpulkan bahwa peubah-peubah yang mempengaruhi kemiskinan rumah tangga di wilayah perkotaan adalah umur kepala rumah tangga, jumlah anggota rumah tangga, tingkat pendidikan tertinggi kepala rumah tangga, dan lapangan usaha/pekerjaan utama kepala rumah tangga. Sedikit berbeda untuk wilayah perdesaan, yaitu selain variabel di perkotaan, faktor jenis kelamin kepala rumah tangga, status perkawinan kepala rumah tangga, status pekerjaan kepala rumah tangga, dan jumlah jam kerja kepala rumah tangga selama seminggu juga mempengaruhi kemiskinan rumah tangga.

Budiarti (2004) yang memberikan gambaran umum karakteristik demografi, sosial, dan ekonomi penduduk miskin di DKI Jakarta di mana sebagian besar kepala rumah tangganya berumur 30-45 tahun, berstatus kawin, pendidikan tertinggi rata-rata SLTP ke bawah dan hampir semuanya tidak buta huruf dengan jumlah anggota rumah tangga lebih dari empat. Penduduk miskin di DKI Jakarta memiliki akses yang rendah terhadap fasilitas air bersih dan fasilitas sanitasi dengan tingkat morbiditas yang lebih tinggi dibandingkan penduduk tidak miskin. Selain itu ada 20 persen penduduk miskin yang menganggur dan mereka yang tidak menganggur bekerja di sektor informal, sebagai buruh/karyawan di lapangan usaha jasa-jasa. 
Penelitian tersebut menyimpulkan bahwa variabel-variabel demografi dan sosial yang mempengaruhi kecenderungan status kemiskinan penduduk di DKI Jakarta adalah umur kepala rumah tangga, jumlah anggota rumah tangga, pendidikan tertinggi yang ditamatkan kepala rumah tangga, morbiditas, akses terhadap fasilitas air bersih dan sanitasi, dan luas lantai per kapita, status pekerjaan utama dan sektor pekerjaan.
Diliana (2005) meneliti perbandingan faktor-faktor yang mempengaruhi pendapatan rumah tangga di Kabupaten Klaten dan Kabupaten Magelang tahun 2003. Faktor-faktor yang signifikan mempengaruhi adalah tempat tinggal, jenis kelamin, tingkat pendidikan, usia, dan jumlah jam kerja. Sedangkan di Kabupaten Magelang adalah status tempat tinggal dan tingkat pendidikan kepala rumah tangga.

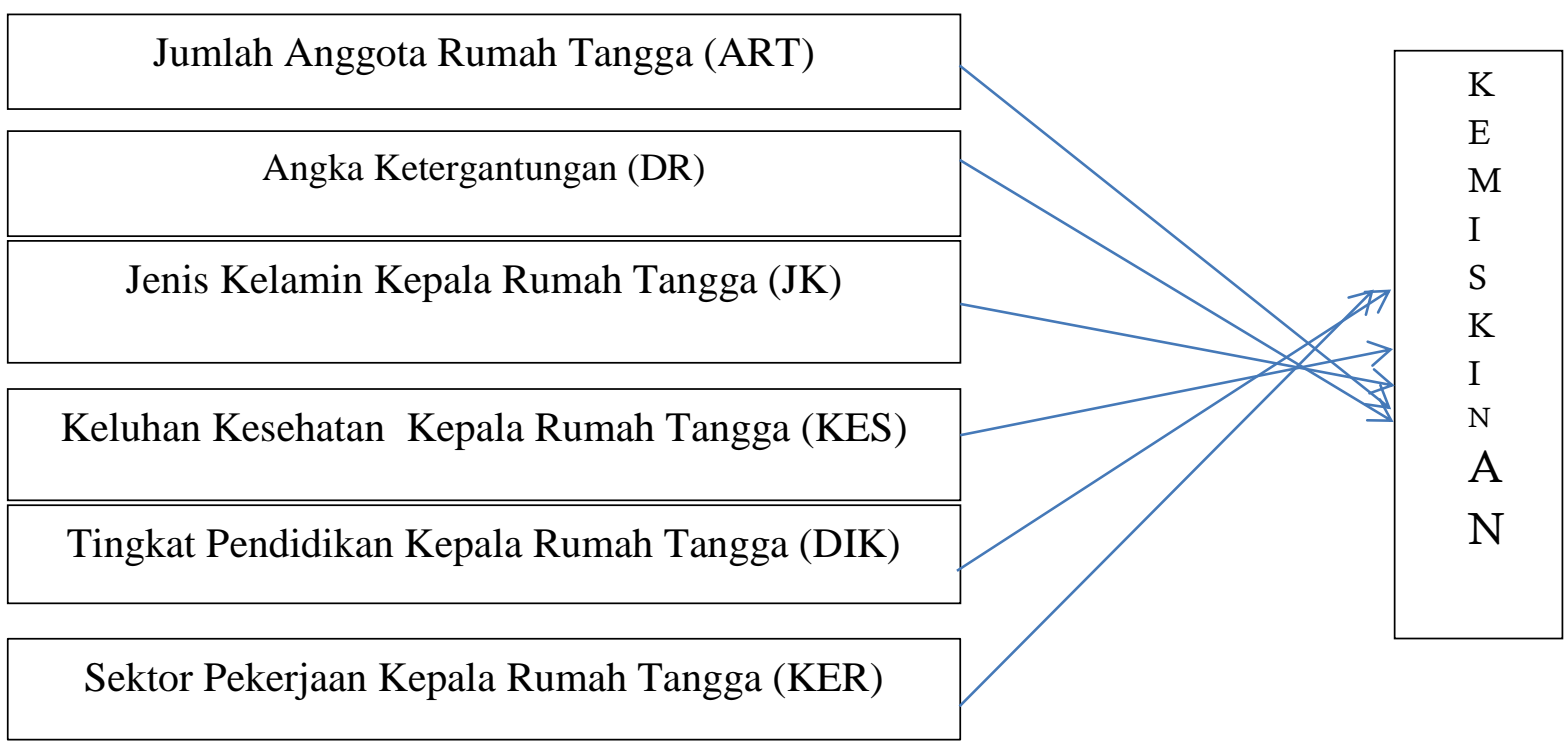

Gambar 4. Alur Kerangka Pemikiran Teoritis

Hipotesis merupakan dugaan sementara yang harus diuji secara empiris. Dengan mengacu pada dasar pemikiran yang bersifat teoritis dan berdasarkan studi empiris yang pernah dilakukan berkaitan dengan penelitian dibidang ini, maka disusun hipotesis sebagai berikut :

Hipotesis : Jumlah anggota rumah tangga, angka ketergantungan, jenis kelmin kepala rumah tangga, keluhan kesehatan kepala rumah tangga, tingkat pendidikan kepala rumah tangga, sektor pekerjaan kepala rumah tanggaberpengaruh terhadap kemiskinan rumah tangga di Kabupaten Semarang

Hipotesis statistik :

$\mathrm{H} 0$ : artinya jumlah anggota rumah tangga, angka ketergantungan, jenis kelmin kepala rumah tangga, keluhan kesehatan kepala

\section{METODE PENELITIAN}

Variabel tak bebas dalam penelitian ini adalah kemiskinan pada rumah tangga (Y), yang dikategorikan menjadi :

Rumah tangga miskin $\quad=1$

Rumah tangga tidak miskin $\quad=0$

Rumah tangga merupakan seseorang atau sekelompok orang yang mendiami sebagian atau seluruh bangunan fisik atau bangunan sensus, dan biasanya tinggal bersama serta makan dari satu dapur.

Rumah tangga miskin adalah rumah tangga yang pengeluaran per kapita per bulan lebih kecil atau sama dengan garis kemiskinan. Garis kemiskinan Kabupaten Semarang tahun 2013 sebesar Rp 263.352 per kapita per bulan (BPS Provinsi Jawa Tengah). 
Variabel bebas dalam penelitian ini terdiri dari :

Jumlah anggota rumah tangga, adalah banyaknya orang yang tinggal dan makan bersama dalam suatu rumah tangga termasuk kepala rumah tangga. Variabel jumlah anggota rumah tangga ini dinotasikan dengan variabel ART (variabel kontinyu).

Angka ketergantungan atau dependency ratio adalah perbandingan antara penduduk usia tidak/belum produktif (umur 0-14 tahun dan umur 65 tahun ke atas) dengan penduduk usia produktif Umur (15-64 tahun). Notasi variabelnya adalah DR (variabel kontinyu).

Keluhan kesehatan kepala rumah tangga adalah apabila seorang kepala rumah tangga mengalami keluhan kesehatan dan menyebabkan aktifitas pekerjaan sehari-hari terganggu sehingga mempengaruhi tingkat produktivitasnya. Notasi variabel dummy adalah KES:

Mengalami keluhan dan terganggu aktifitas $=1$ Tidak mengalami keluhan atau mengalami keluhan tapi tidak terganggu aktifitas $=0$

Jenis kelamin adalah jenis kelamin kepala rumahtanga, merupakan variabel dummyyang dinotasikan dengan JK:

$\begin{array}{lll}\text { Perempuan } & = & 1 \\ \text { Laki-laki } & = & 0\end{array}$

Tingkat pendidikan atau pendidikan tertinggi yang ditamatkan kepala rumah tangga, notasi variabel dummy adalah DIK dikelompokkan menjadi :

Tidak/belum pernah sekolah = 4

Lulus SD $=3$

Lulus SLTP $=2$

Lulus SLTA $\quad=1$

Perguruan Tinggi = 0

Sektor pekerjaan kepala rumah tangga adalah bidang kegiatan dari pekerjaan/perusahaan/instansi tempat kepala rumah tangga bekerja, klasifikasi lapangan usaha menggunakan Klasifikasi Baku Lapangan Usaha Indonesia (KBLI) 2009 yang diterbitkan BPS. Variabel dummy sektor pekerjaan dinotasikan dengan KER:

$\begin{array}{lc}\text { Primer (Pertanian, } & \text { Pertambangan/ } \\ \text { Penggalian)/tidak bekerja } & =1\end{array}$

Lainnya

$$
=0
$$

Data yang digunakan dalam penelitian ini merupakan data primer/data mentah hasil pendataan Survei Sosial Ekonomi Nasional (Susenas) yang dilakukan oleh Badan Pusat Statistik Kabupaten Semarang pada tahun 2013, dengan jumlah sampel sebanyak 791 rumah tanggayang tersebar di 19 kecamatan. Data diolah dengan menggunakan programSPSS 16.0.

Teknik analisis yang akan digunakan untuk menguji hipotesis ini adalah analisis deskriptif dan analisis regresi logistik.

Analisis deskriptif dengan tabulasi silang (cross tab) adalah metode analisis yang sederhana, namun dapat digunakan untuk menjelaskan hubungan antar variabel. Dalam analisis ini ditampilkan tabulasi silang antara variabel yang dijelaskan (kemiskinan rumah tangga) dan variabel penjelas.

Wold Bank Institute (2002) dalam penjelasan teoritis menjelaskan bahwa dalam menganalisis kemiskinan menggunakan pendekatan konsumsi rumah tangga atau pengeluaran per kapita, dan fungsi pengeluaran akan memfasilitasi analisis yang sederhana. Dalam bentuk yang sederhana, fungsi pengeluaran ditunjukkan oleh persamaan yi = $\mathrm{p} \cdot \mathrm{q}=\mathrm{e}(\mathrm{p}, \mathrm{x}, \mathrm{u})$. Kemudian dalam menganalisis determinan kemiskinan, lebih lanjut dijelaskan dengan teknik regresi semilog seperti persamaan Log wi $=\gamma \mathrm{Xi}+$ ci. Namun beberapa peneliti lebih suka menggunakan bentuk variabel biner (dua kategori) pada sisi kiri (variabel tak bebas) persamaan di atas untuk memudahkan dalam analisis. Dengan demikian diperoleh nilai variabel tak bebas yang bernilai 1 (satu) untuk rumah tangga miskin (yang pengeluaran/konsumsi per kapitanya lebih rendah atau sama dengan garis kemiskinan) dan bernilai 0 untuk yang lain. Oleh karena itu dalam penelitian ini digunakan analisis regresi logistic (Model Logit).

Analisis regresi logistic (Model Logit) seperti dijelaskan Nachrowi (2002) dan Ramanathan (1998) digunakan untuk menganalisis data yang peubah responnya bernilai 1 dan 0 (berskala biner). $Y=1$ menyatakan kejadian yang "sukses", yaitu 
rumah tangga miskin dan $\mathrm{Y}=0$ menyatakan kejadian yang "gagal" atau rumah tangga yang tidak miskin. Peubah tersebut mengikuti sebaran Bernoulli, sedangkan peubah penjelasnya dapat berskala biner, kategori atau kontinyu.
Persamaan regresi logistik (model logit) secara matematis diderivasi dari suatu nilai peluang terjadinya suatu peristiwa yang didefinisikan dengan persamaan:

$$
p_{i}=\frac{1}{1+e^{-Z_{i}}}, \quad \operatorname{dimana} \quad z_{i}=\left(\beta_{0}+\beta_{1} x_{1}+\beta_{2} x_{2}+\ldots+\beta_{k} x_{k}\right) \quad \ldots \ldots \ldots
$$

$$
1-p_{i}=1-\frac{1}{1+e^{-Z_{i}}}=\frac{e^{-Z_{i}}}{1+e^{-Z_{i}}}
$$

rasio antara $\mathrm{p}_{\mathrm{i}}$ dan $1-\mathrm{p}_{\mathrm{i}}$ adalah

$$
\frac{p_{i}}{1-p_{i}}=\frac{\left(\frac{1}{1+e^{-Z_{i}}}\right)}{\left(\frac{e^{-Z_{i}}}{1+e^{-Z_{i}}}\right)}=\frac{1}{e^{-Z_{i}}}=e^{Z_{i}}=e^{\left(\beta_{0}+\beta_{1} x_{1}+\beta_{2} x_{2}+\ldots+\beta_{k} x_{k}\right)} \quad \ldots \ldots
$$

Angka ini disebut Odd atau resiko yaitu perbandingan antara peluang terjadinya suatu peristiwa dengan peluang tidak terjadinya suatu peristiwa. Bila nilai odd ini di-log-kan, maka akan didapatkan log odd sebagai berikut:

$$
L_{i}=\ln \left(\frac{p_{i}}{1-p_{i}}\right)=Z_{i}=\beta_{0}+\beta_{1} x_{1}+\beta_{2} x_{2}+\ldots+\beta_{k} x_{k}
$$

Dengan penurunan rumus dari persamaan (1), dimana $p_{i}$ mengikuti fungsi distribusi logistic, sehingga diperoleh bentuk persamaan (3) yang demikian merupakan Model Logit . catatan::

L disebut Log odd atau Model Logit

L linier dalam X, juga linier dalam $\beta_{\mathrm{i}}$
Karena $\mathrm{p}$ terletak antara 0 dan 1 , maka $\mathrm{L}$ terletak antara - $\infty$ dan $\infty$

Meskipun L linier dalam X, tetapi $\mathrm{p}$ tidak linier dalam $\mathrm{X}$

$\beta_{\mathrm{i}}$ menyatakan perubahan dalam $\mathrm{L}_{\mathrm{i}}$ bila $\mathrm{X}_{\mathrm{i}}$ berubah 1 unit $(i=1,2, \ldots, \mathrm{k})$ dan $\beta_{0}$ menyatakan log odd pada saat nilai $X$ sama dengan nol.

Sehingga model logit untuk analisis dalam penelitian ini adalah:

$$
\begin{gathered}
\mathrm{L}_{\mathrm{i}}=\beta_{\mathrm{O}}+\beta_{\mathrm{DT}} \mathrm{D}_{\mathrm{DT}}+\beta_{\mathrm{ART}} \mathrm{D}_{\mathrm{ART}}+\beta_{\mathrm{DR}} \mathrm{V}_{\mathrm{DR}}+\beta_{\mathrm{AIR}} \mathrm{D}_{\mathrm{AIR}}+\beta_{\mathrm{KES}} \mathrm{D}_{\mathrm{KES}}+ \\
\beta_{\mathrm{JK}} \mathrm{D}_{\mathrm{JK}}+\beta_{\mathrm{UM}} \mathrm{D}_{\mathrm{UM}}+\beta_{\mathrm{DIK}} \mathrm{D}_{\mathrm{DIK}}+\beta_{\mathrm{KER}} \mathrm{D}_{\mathrm{KER}}
\end{gathered}
$$

Dimana $\beta_{0}=$ intersep, $\beta_{\mathrm{DT}} . . \beta_{\mathrm{KER} 2}=$ koefisien regresi, $D_{\mathrm{DT}} . . \mathrm{D}_{\mathrm{KER} 2}=$ variabel bebas

Salah satu cara mengestimasi parameter model logit adalah menggunakan metode Maximum Likelihood (Nachrowi, 2002). Misal $\mathrm{L}$ (x) seperti pada persamaan (3.4) adalah fungsi likelihood yang menyatakan probabilitas bersama dari data hasil observasi yang masih merupakan fungsi dari parameter yang tidak diketahui. Penaksiran parameter fungsi likelihood $\mathrm{L}\left(\beta_{1}, \beta_{2}, \ldots, \beta_{p}\right)$ ini adalah dilakukan dengan mencari suatu nilai $\hat{\beta}_{1}, \hat{\beta}_{2}, \ldots, \hat{\beta}_{p}$ yang dapat memaksimumkan nilai $\mathrm{L}\left(\beta_{1}, \beta_{2}, \ldots, \beta_{p}\right)$. 
Oleh karenanya $\hat{\beta}_{1}, \hat{\beta}_{2}, \ldots, \hat{\beta}_{p}$ disebut taksiran maksimum likelihood (Maximum Likelihood Estimator/MLE). Penghitungan parameterparameter tersebut akan sangat mudah diperoleh dengan bantuan software SPSS.

Analisis model logit ini digunakan untuk mengestimasi rasio kecenderungan (odds ratio) setiap faktor yang berpengaruh terhadap kemiskinan rumah tangga di Kabupaten Semarang. Peubah penjelas yang digunakan bisa bersifat kualitatif dan kuantitatif. Untuk memudahkan analisis, beberapa peubah kuanlitatif dilakukan pengkategorian sehingga peubah-peubah tersebut menjadi berskala nominal atau ordinal, kemudian peubah-peubah tersebut dibuat dalam bentuk dummy. Data kategori dengan " $n$ " kategori, dibuat variabel dummy sebanyak "n-1" dengan satu buah kategori akan dijadikan sebagai kategori referensi. Dengan metode backward stepwise (Wald) model logit pada persamaan (4) (menggunakan program SPSS) akan diperoleh variable-variabel bebas yang memberikan nilai koefisien determinasi terbesar dan telah mengeliminir multikolinieritas antar variabel bebas. Nilai-nilai parameter dan nilai statistik lainnya yang diberikan merupakan hasil dari model yang paling baik. Dengan demikian akan diketahui faktor-faktor yang mempengaruhi secara signifikan terhadap kemiskinan rumah tangga di Kabupaten Semarang.

Untuk menguji signifikansi model digunakan statistik uji $\mathrm{G}^{2}$. Statistik uji ini digunakan untuk menguji kesesuaian model dengan melihat semua peubah bebas dalam model. Hipotesis yang digunakan adalah:

$\mathrm{H}_{0} \quad: \beta_{1}=\beta_{2}=\ldots=\beta_{\mathrm{k}}=0$

Artinya tidak ada pengaruh antara peubah penjelas dengan kemiskinan

$\mathrm{H}_{1} \quad$ : minimal terdapat satu $\beta_{\mathrm{i}} \neq 0$ Artinya ada pengaruh antara peubah penjelas dengan kemiskinan, dimana $\mathrm{i}=$ variabel penjelas Statistik ujinya adalah :

$G^{2}=-2 \ln \left(\frac{L_{0}}{L_{1}}\right)$
Dimana $\mathrm{L}_{0}$ adalah likelihood tanpa peubah penjelas dan $\mathrm{L}_{1}$ adalah likelihood dengan peubah penjelas. Statistik uji $\mathrm{G}^{2}$ mengikuti sebaran $\chi^{2}$ dengan derajat bebas $\mathrm{k}$, sehingga tolak $\mathrm{H}_{0}$ jika $\mathrm{G}^{2}>\chi_{(\alpha ; k)}^{2}$ atau $p$-value $<\alpha$ yang berarti dapat disimpulkan bahwa peubah penjelas secara keseluruhan mempengaruhi peubah kemiskinan.

Untuk pengujian parameter digunakan statistik uji Wald $\left(\mathrm{W}_{\mathrm{i}}\right)$. Statistik uji ini digunakan untuk menguji koefisien regresi secara parsial dalam model regresi logistik. Hipotesis yang digunakan adalah:

$\mathrm{H}_{0} \quad: \beta \mathrm{i}=0$ artinya tidak ada pengaruh antara peubah penjelas ke-i dengan kemiskinan $\mathrm{H}_{1} \quad: \beta_{\mathrm{i}} \neq 0$ artinya ada pengaruh antara peubah penjelas ke-i dan kemiskinan Statistik ujinya adalah

$$
W_{i}=\left(\frac{\hat{\beta}_{i}}{\operatorname{SE}\left(\hat{\beta}_{i}\right)}\right)^{2}
$$

$$
\begin{aligned}
& \text { dimana } \hat{\beta}_{i} \quad=\text { penduga } \beta_{i} \\
& \operatorname{SE}(\hat{\beta})_{i} \quad=\text { simpangan baku penduga } \beta_{i}
\end{aligned}
$$

$W_{i}$ mengikuti sebaran $\chi^{2}$ dengan derajat bebas $1 . \mathrm{H}_{0}$ ditolak jika $W_{i}>\chi_{(\alpha ; 1)}^{2}$ atau $p$-value $<\alpha$ dan dapat disimpulkan bahwa peubah penjelas secara parsial (sendiri-sendiri) berpengaruh terhadap kemiskinan.

Rasio kecenderungan (odds ratio) merupakan suatu ukuran untuk mengetahui tingkat risiko (kecenderungan), yaitu perbandingan antara peluang dua peubah penjelas $\mathrm{Xi}$, antara kejadian-kejadian yang masuk kategori sukses dan yang gagal. Dalam penelitian ini rasio kecenderungan (odds ratio) digunakan untuk mengetahui kecenderungan faktor-faktor yang berpengaruh terhadap kemiskinan di Kabupaten Semarang.

Bila peubah bebas merupakan peubah kategori dengan dua kategori, interpretasi parameter dilakukan dengan cara membandingkan nilai odds dari salah satu nilai pada peubah tersebut dengan nilai odds dari nilai lainnya (referensi). Misalkan kedua kategori tersebut adalah 1 dan 0 (sebagai referensi), maka interpretasi koefisien pada peubah ini adalah rasio dari nilai odds untuk kategori 1 terhadap 
nilai odds untuk kategori 0 , dimana $p\left(x_{i}=1\right)=p(1)$ dan $p\left(x_{i}=0\right)=p(0)$. Odds ratio dituliskan menjadi:

$$
\psi=\left(\frac{p(1)}{1-p(1)} / \frac{p(0)}{1-p(0)}\right)=\left(\left[\frac{p(1)}{1-p(1)}\right] \cdot\left[\frac{1-p(0)}{p(0)}\right]\right)
$$$$
=\left(\frac{\left[\frac{\exp \left(\beta_{0}+\beta_{i}\right)}{1+\exp \left(\beta_{0}+\beta_{i}\right)}\right]}{\left[\frac{1}{1+\exp \left(\beta_{0}+\beta_{i}\right)}\right]} \cdot \frac{\left[\frac{1}{1+\exp \left(\beta_{0}\right)}\right]}{\left[\frac{\exp \left(\beta_{0}\right)}{1+\exp \left(\beta_{0}\right)}\right]}\right)
$$$$
=\left(\frac{\exp \left(\beta_{0}+\beta_{i}\right)}{\exp \left(\beta_{0}\right)}\right)=\exp \left(\beta_{i}\right)
$$

(5)

Sehingga

$$
\psi=\left(\frac{p\left(x_{i}=1\right)}{1-p\left(x_{i}=1\right)} / \frac{p\left(x_{i}=0\right)}{1-p\left(x_{i}=0\right)}\right)=\exp \left(\beta_{i}\right)
$$

Artinya risiko terjadinya peristiwa $\mathrm{Y}=1$

(kejadian sukses) pada kategori $x_{i}=1$ adalah sebesar $\exp \left(\beta_{i}\right)$ kali risiko terjadinya kejadian $\mathrm{Y}=1$ (kejadian sukses) pada kategori $x_{i}=0$. Sedangkan jika variabel kontinyu, diartikan bahwa dengan peningkatan sebesar $\mathrm{c}$ unit satuan, maka resiko terjadinya kejadian sukses sebesar $\exp \left(c . \beta_{i}\right)$ kali lebih besar dibandingkan dengan sebelumnya. Nilai estimasi dari odds ratio diperoleh dengan mengeksponensialkan koefisien regresi logistik masing-masing peubah penjelas yang signifikan berhubungan dengan peubah respon.

\section{HASIL DAN PEMBAHASAN}

Pembahasan terhadap faktor-faktor yang mempengaruhi kemiskinan rumah tangga di Kabupaten Semarang dilakukan dengan analisis tabulasi silang antara kemiskinan rumah tangga dan variabel-variabelyang mempengaruhinya. Analisis ini hanyalah menggambarkan tingkat hubungan antar variabel tanpa mempertimbangkan sebab dan akibat.

Tabel 2. Jumlah Rumah Tangga Sampel Menurut Jumlah Anggota Rumah Tangga

\begin{tabular}{|c|c|c|c|c|}
\hline \multirow{2}{*}{$\begin{array}{l}\text { Jumlah } \\
\text { Tangga }\end{array}$} & \multirow[t]{2}{*}{ Anggota } & \multicolumn{2}{|c|}{ Rumah Kemiskinan Rumah Tangga } & \multirow{2}{*}{ Total } \\
\hline & & Tidak Miskin & Miskin & \\
\hline \multirow{3}{*}{\multicolumn{2}{|c|}{$1-2$}} & 182 & 4 & 186 \\
\hline & & $97.8 \%$ & $2.2 \%$ & $100.0 \%$ \\
\hline & & $24.5 \%$ & $8.3 \%$ & $23.5 \%$ \\
\hline \multirow{3}{*}{\multicolumn{2}{|c|}{$3-4$}} & 381 & 18 & 399 \\
\hline & & $95.5 \%$ & $4.5 \%$ & $100.0 \%$ \\
\hline & & $51.3 \%$ & $37.5 \%$ & $50.4 \%$ \\
\hline \multirow{3}{*}{\multicolumn{2}{|c|}{$5+$}} & 180 & 26 & 206 \\
\hline & & $87.4 \%$ & $12.6 \%$ & 100.0 \\
\hline & & $24.2 \%$ & $54.2 \%$ & $26.0 \%$ \\
\hline \multirow{3}{*}{\multicolumn{2}{|c|}{ Total }} & 743 & 48 & 791 \\
\hline & & $93.9 \%$ & $6.1 \%$ & $100.0 \%$ \\
\hline & & $100.0 \%$ & $100.0 \%$ & $100.0 \%$ \\
\hline
\end{tabular}
Dan Kemiskinan di Kabupaten Semarang Tahun 2013

Rumah tangga dengan jumlah anggota rumah tangga 1-2 orang yang termasuk kelompok miskin persentasenya jauh lebih kecil daripada rumah tangga dengan anggota rumah tangga3-4 orang, dan lebih kecil lagi dibandingkan dengan anggota rumah tangga5 orang atau lebih, yaitu 
masing-masing sebesar 8,3 persen, 37,5 persen dan 54,2 persen. Hal ini menunjukkan bahwa semakin besar anggota rumah tangga, maka semakin besar kemungkinan untuk menjadi miskin. Dengan kata lain bahwa ada hubungan antara kemiskinan dan jumlah anggota rumah tangga yang harus ditangung kepala rumah tangga. Angka Ketergantungan (Dependency Ratio), Jika dikaitkan dengan kemiskinan, maka semakin besar angka ketergantungan, maka cenderung semakin besar pula kemungkinan suatu rumah tangga menjadi miskin.

Hal ini terlihat dari Tabel 5.2 yang menunjukkan bahwa persentase rumah tangga miskin dengan angka ketergantungan di bawah setengah (0-49 persen) hanya 14,6 persen, sedangkan rumah tanggamiskin dengan angka ketergantungan yang lebih tinggi, persentasenya cenderung makin besar yaitu 27,1 persen untuk angka ketergantungan 0,5 sampai dengan 0,9, sebesar 22,9 persen untuk angka ketergantungan 1,0 sampai dengan 1,49 dan mencapai 35,4 persen untuk rumah tangga dengan angka ketergantungan satu setengah atau lebih.

Tabel 3. Jumlah Rumah Tangga Sampel Menurut Angka Ketergantungan Dan Kemiskinan di Kabupaten Semarang Tahun 2013

\begin{tabular}{llll}
\hline Angka Ketergantungan & \multicolumn{2}{l}{ Kemiskinan Rumah Tangga } \\
& Tidak miskin & Miskin & Total \\
\hline$<0,5$ & 332 & 7 & 339 \\
& $97.9 \%$ & $2.1 \%$ & $100.0 \%$ \\
$0,5-0,9$ & $44.7 \%$ & $14.6 \%$ & $42.9 \%$ \\
& 190 & 13 & 203 \\
& $93.6 \%$ & $6.4 \%$ & $100.0 \%$ \\
$1,0-1,49$ & $25.6 \%$ & $27.1 \%$ & $25.7 \%$ \\
& 128 & 11 & 139 \\
$1,5+$ & $92.1 \%$ & $7.9 \%$ & $100.0 \%$ \\
& $17.2 \%$ & $22.9 \%$ & $17.6 \%$ \\
& 93 & 17 & 110 \\
Total & $84.5 \%$ & $15.5 \%$ & $100.0 \%$ \\
& $12.5 \%$ & $35.4 \%$ & $13.9 \%$ \\
& 743 & 48 & 791 \\
& $93.9 \%$ & $6.1 \%$ & $100.0 \%$ \\
\hline
\end{tabular}

Jenis Kelamin Kepala Rumah tangga, Secara keseluruhan rumah tangga yang dikepalai oleh laki-laki sebanyak 85,0 persen dan yang dikepalai oleh perempuan sebanyak 15,0 persen (lihat Tabel 5-3). Sedangkan pada kelompok rumah tanggamiskin yang dikepalai laki-laki sebanyak 87,5 persen dan yang dikepalai perempuan lebih banyak yaitu sebesar12,5 persen. Apabila kita lihat besaran angka-angka tersebut tidak berbeda significant perbandingan jenis kelamin kepala rumah tangga untuk kelompok rumah tangga miskin dengan rumah tangga secara keseluruhan. Di samping itu angka-angka pada Tabel 5.3 tidak menunjukkan bahwa kepala rumah tangga perempuan banyak ditemukan pada kelompok rumah tangga miskin. Hal ini mengindikasikan bahwa jenis kelamin kepala rumah tangga dalam penelitian ini kurang berpengaruh terhadap kemiskinan rumah tangga. 
Tabel 4. Jumlah Rumah Tangga Sampel Menurut Jenis Kelamin Kepala Rumah Tangga Dan Kemiskinan di Kabupaten Semarang Tahun 2013

\begin{tabular}{llll}
\hline \multirow{2}{*}{$\begin{array}{l}\text { Renis Kelamin } \\
\text { Rumah Tangga }\end{array}$} & Kepala Kemiskinan Rumah Tangga & \\
& Tidak miskin & Miskin & Total \\
\hline Laki-laki & 630 & 42 & 672 \\
& $93.8 \%$ & $6.2 \%$ & $100.0 \%$ \\
Perempuan & $84.8 \%$ & $87.5 \%$ & $85.0 \%$ \\
& 113 & 6 & 119 \\
& $95.0 \%$ & $5.0 \%$ & $100.0 \%$ \\
Total & $15.2 \%$ & $12.5 \%$ & $15.0 \%$ \\
& 743 & 48 & 791 \\
& $93.9 \%$ & $6.1 \%$ & $100.0 \%$ \\
& $100.0 \%$ & $100.0 \%$ & $100.0 \%$ \\
\hline
\end{tabular}

Tabel 5. Jumlah Rumah Tangga Sampel Menurut Keluhan Kesehatan Kepala Rumah Tangga Dan Kemiskinan di Kabupaten Semarang Tahun 2013

\begin{tabular}{llll}
\hline $\begin{array}{l}\text { Keluhan Kesehatan } \\
\text { Rumah Tangga }\end{array}$ & Kepala & \multicolumn{2}{l}{ Kemiskinan Rumah Tangga } \\
& Tidak miskin & Miskin & Total \\
\hline $\begin{array}{l}\text { Tidak mengalami keluhan } \\
\text { kesehatan atau mengalami }\end{array}$ & 629 & 43 & 672 \\
keluhan tapi tidak terganggu & $93.6 \%$ & $6.4 \%$ & $100.0 \%$ \\
Mengalami keluhan kesehatan & $84.7 \%$ & $89.6 \%$ & $85.0 \%$ \\
dan terganggu & 114 & 5 & 119 \\
& $95.8 \%$ & $4.2 \%$ & $100.0 \%$ \\
Total & $15.3 \%$ & $10.4 \%$ & $15.0 \%$ \\
& 743 & 48 & 791 \\
& $93.9 \%$ & $6.1 \%$ & $100.0 \%$ \\
\hline
\end{tabular}

Tabel 5.4 menunjukkan bahwa kepala rumah tangga yang mengalami keluhan kesehatan dan menyebabkan terganggunya aktifitas sehari-hari sedikit berpengaruh terhadap kemiskinan rumah tangga.

Yaitu dari keseluruhan sampel rumah tangga hanya 15,0 persen rumah tangga yang kepala rumah tangganya mengalami keluhan kesehatan dan terganggu aktivitas sehariharinya dan tercatat 85,0 persen kepalarumah tangga tidak mengalami keluhan kesehatan atau mengalami keluhan kesehatan tetapi tidak terganggu aktivitas sehari-harinya. Sedangkan pada kelompok rumah tangga miskin hanya 10,4 persen rumah tangga yang kepala rumah tangganya mengalami keluhan kesehatan dan terganggu aktivitasnya. Tingkat Pendidikan Kepala Rumah tangga, Pada tabel 5.5 tersebut dapat dilihat bahwa pada kelompok rumah tangga miskin semakin rendah tingkat pendidikan kepala rumah tangga maka semakin tinggi peluang rumah tangga tersebut menjadi miskin. Terbukti bahwa pendidikan kepala rumah tangga miskin sebagian besar tidak tamat SD, yaitu mencapai 47,9 persen. Kepala rumah tangga miskin yang hanya tamat SD sebesar 37,5 persen, yang hanya tamat SLTP sebesar 8,3 persen, yang tamat SLTA hanya 6,2 persen, dan 
kepala rumah tangga miskin yang mengenyam pendidikan sampai perguruan tinggi 0 persen.

mempunyai hubungan dengan kemiskinan Hal ini menunjukkan bahwa tingkat pendidikan

rumah tangga.

Tabel 6. Jumlah Rumah Tangga Sampel Menurut Tingkat Pendidikan Kepala Rumah Tangga Dan Kemiskinan di Kabupaten Semarang Tahun 2013

\begin{tabular}{clll}
\hline Tingkat $\begin{array}{l}\text { Pendidikan } \\
\text { Kepala Rumah Tangga }\end{array}$ & \multicolumn{2}{l}{ Kemiskinan Rumah Tangga } \\
& Tidak miskin & Miskin & Total \\
\hline Perguruan Tinggi & 47 & 0 & 47 \\
& $100.0 \%$ & $.0 \%$ & $100.0 \%$ \\
\multirow{2}{*}{ Tamat SLTA } & $6.3 \%$ & $.0 \%$ & $5.9 \%$ \\
& 153 & 3 & 156 \\
Tamat SLTP & $98.1 \%$ & $1.9 \%$ & $100.0 \%$ \\
& $20.6 \%$ & $6.2 \%$ & $19.7 \%$ \\
Tamat SD & 109 & 4 & 113 \\
& $96.5 \%$ & $3.5 \%$ & $100.0 \%$ \\
Tidak Tamat SD & $14.7 \%$ & $8.3 \%$ & $14.3 \%$ \\
& 240 & 18 & 258 \\
& $93.0 \%$ & $7.0 \%$ & $100.0 \%$ \\
Total & $32.3 \%$ & $37.5 \%$ & $32.6 \%$ \\
& 194 & 23 & 217 \\
& $89.4 \%$ & $10.6 \%$ & $100.0 \%$ \\
& $26.1 \%$ & $47.9 \%$ & $27.4 \%$ \\
& 743 & 48 & 791 \\
& $93.9 \%$ & $6.1 \%$ & $100.0 \%$ \\
& $100.0 \%$ & $100.0 \%$ & $100.0 \%$ \\
\hline
\end{tabular}

Sektor Pekerjaan Kepala Rumah tangga, industri, perdagangan, atau jasa), biasanya Sektor/lapangan pekerjaan kepala rumah tangga merupakan daerah yang maju dan berkembang. dikelompokkan menjadi dua sektor yaitu sektor Demikian pula untuk rumah tangga yang primer (pertanian dan pertambangan) dan sektor bergerak di sektor non primer, tentunya non primer. Sektor pekerjaan merupakan salah mempunyai peluang yang lebih kecil untuk satu indikator kemajuan atau kesejahteraan. terjerat dalam kemiskinan.

Daerah yang potensi sektor non primer (misal

Tabel 7. Jumlah Rumah Tangga Sampel Menurut Sektor PekerjaanKepala Rumah Tangga Dan Kemiskinan di Kabupaten Semarang Tahun 2013 


\begin{tabular}{lllll}
\hline $\begin{array}{l}\text { Sektor Pekerjaan } \\
\text { Rumah Tangga }\end{array}$ & Kepala & \multicolumn{2}{l}{ Kemiskinan Rumah Tangga } \\
& Tidak miskin & Miskin & Total \\
\hline Sektor Lainnya & 425 & 14 & 439 \\
& & $96.8 \%$ & $3.2 \%$ & $100.0 \%$ \\
& & $57.2 \%$ & $29.2 \%$ & $55.5 \%$ \\
Tidak bekerja/Kerja & di & 318 & 34 & 352 \\
sektor Primer & & $90.3 \%$ & $9.7 \%$ & $100.0 \%$ \\
& $42.8 \%$ & $70.8 \%$ & $44.5 \%$ \\
Total & 743 & 48 & 791 \\
& $93.9 \%$ & $6.1 \%$ & $100.0 \%$ \\
& $100.0 \%$ & $100.0 \%$ & $100.0 \%$ \\
\hline
\end{tabular}

Analisis Regresi Logistik, Berbeda dengan analisis tabulasi silang yang telah diuraikan sebelumnya, analisis regresi logistik (logit) dapat menjelaskan tingkat maupun arah hubungan variabel-variabel yang berhubungan atau

$$
\mathrm{L}(\mathrm{Y})=\ln \left(\frac{p_{Y}}{1-p_{Y}}\right)=-9,552+1,056 \mathrm{ART}+0,697 \mathrm{DR}-0,725 \mathrm{JK}-0,777 \mathrm{KES}+
$$

\section{0,640 DIK + 0,851 KER}

Uji Kelayakan dan Signifikansi Model ,menurut Santoso (2002) menilai kelayakan model regresi logistik adalah dengan uji Hosmer and Lemeshow Test, yaitu uji Goodness of Fit test (GoF) untuk menentukan apakah model yang dibentuk sudah tepat atau tidak. Model dikatakan tepat apabila tidak ada perbedaan signifikan antara model dengan observasi. Sehingga hipotesisnya adalah sebagai berikut :

$\mathrm{H}_{0}$ : Tidak ada perbedaan yang nyata antara klasifikasi yang diprediksi dengan klasifikasi yang diamati.

$\mathrm{H}_{1}$ : Ada perbedaan yang nyata antara klasifikasi yang diprediksi dengan klasifikasi yang diamati.

Uji ini diukur dengan nilai Chi_Square, dimana nilai Chi_Square tabel $(0,05,6)$ adalah sebesar 16,750. Dari hasil olah data diperoleh nilai Chi_Square Hosmer and Lemeshowhitung sebesar 21,232 (> Chi_Square tabel 16,750) dan nilai signifikansi sebesar $0,007(<0,05)$ sehingga $\mathrm{H}_{0}$ ditolakyang berarti model regresi layak dipakai untuk analisis selanjutnya, karena tidak ada perbedaan yang nyata antara klasifikasi yang diprediksi dengan klasifikasi yang diamati.

Pengujian berikutnya adalah uji keseluruhan model menggunakan statistik uji $\mathrm{G}^{2}$ dengan hipotesis:

$\mathrm{H}_{0}$ : Tidak ada pengaruh antara peubah penjelas dengan kemiskinan $\left(\beta_{\mathrm{i}}=0\right)$

$\mathrm{H}_{1}$ : Ada pengaruh antara peubah penjelas dengan kemiskinan (minimal terdapat satu $\beta_{\mathrm{i}} \neq 0$ ) dimana $\mathrm{i}=$ variabel penjelas).

Dari hasil pengolahan memperlihatkan bahwa

$$
G^{2}=-2 \ln \left(\frac{L_{0}}{L_{1}}\right)=75,876 \text { (p_value }=
$$

0,000) dimana nilai ini jauh lebih besar dari angka $\chi_{(0,05 ; 6)}^{2}=12,592$ serta nilai signifikansi yang jauh lebih kecil dari 0,05 , sehingga $\mathrm{H}_{0}$ ditolak. Dengan kata lain bahwa model regresi logistik tersebut dapat disimpulkan signifikan dan merupakan model yang dapat digunakan untuk menjelaskan kemiskinan.

Tingkat keakuratan data dalam menjelaskan kemiskinan pada model logit dapat 
dilihat dari peningkatan nilai overall classification table pada setiap step. Terlihat bahwa nilai overall percentage pada step_0 sebesar 93,9 persen kemudian meningkat pada step_1 yaitu sebesar 94,2 persen. Hal ini menandakan bahwa secara keseluruhan variabel-variabel penjelas dapat menjelaskan sampai 94,2 persen terhadap kemiskinan rumah tangga.

Pengujian Parameter, setelah diketahui bahwa model regresi tersebut signifikan dan merupakan model yang baik, selanjutnya dilakukan pengujian dengan uji masing-masing parameter dengan menggunakan statistik uji Wald yang mengikuti sebaran $\chi_{(0,05 ; 1)}^{2}$. Nilai hasil pengolahan untuk uji masing-masing variabel dan parameter statistiknya dapat dilihat pada Tabel 5.7pada kolom (4) adalah nilai Wald dan signifikansinya pada kolom (6).Terlihat bahwa variabel jumlah anggota rumah tangga (ART), angka ketergantungan (DR), tingkat pendidikan kepala rumah tangga (DIK), dan sektor pekerjaan kepala rumah tangga mempunyai nilai signifikansi (Sig.) lebih kecil dari 0,05, yang berarti dapat disimpulkan bahwa variabelvariabel tersebut mempengaruhi kemiskinan rumah tangga.

Nilai Wald yang besar menunjukkan bahwa variabel tersebut sangat signifikan mempengaruhi kemiskinan. Nilai statistik uji Wald berlawanan dengan nilai signifikansinya, semakin besar nilai Wald semakin kecil nilai signifikansinya, artinya variabel tersebut semakin signifikan mempengaruhi kemiskinan rumah tangga. Dalam kasus ini berturut-turut variabel yang paling besar pengaruhnya terhadap kemiskinan rumah tangga adalah angka ketergantungan, jumlah anggota rumah tangga, tingkat pendidikan, dan sektor pekerjaan.

Tabel 7. Hasil Pengolahan Model Regresi Logistik Menurut Variabel dan Parameter Statistik

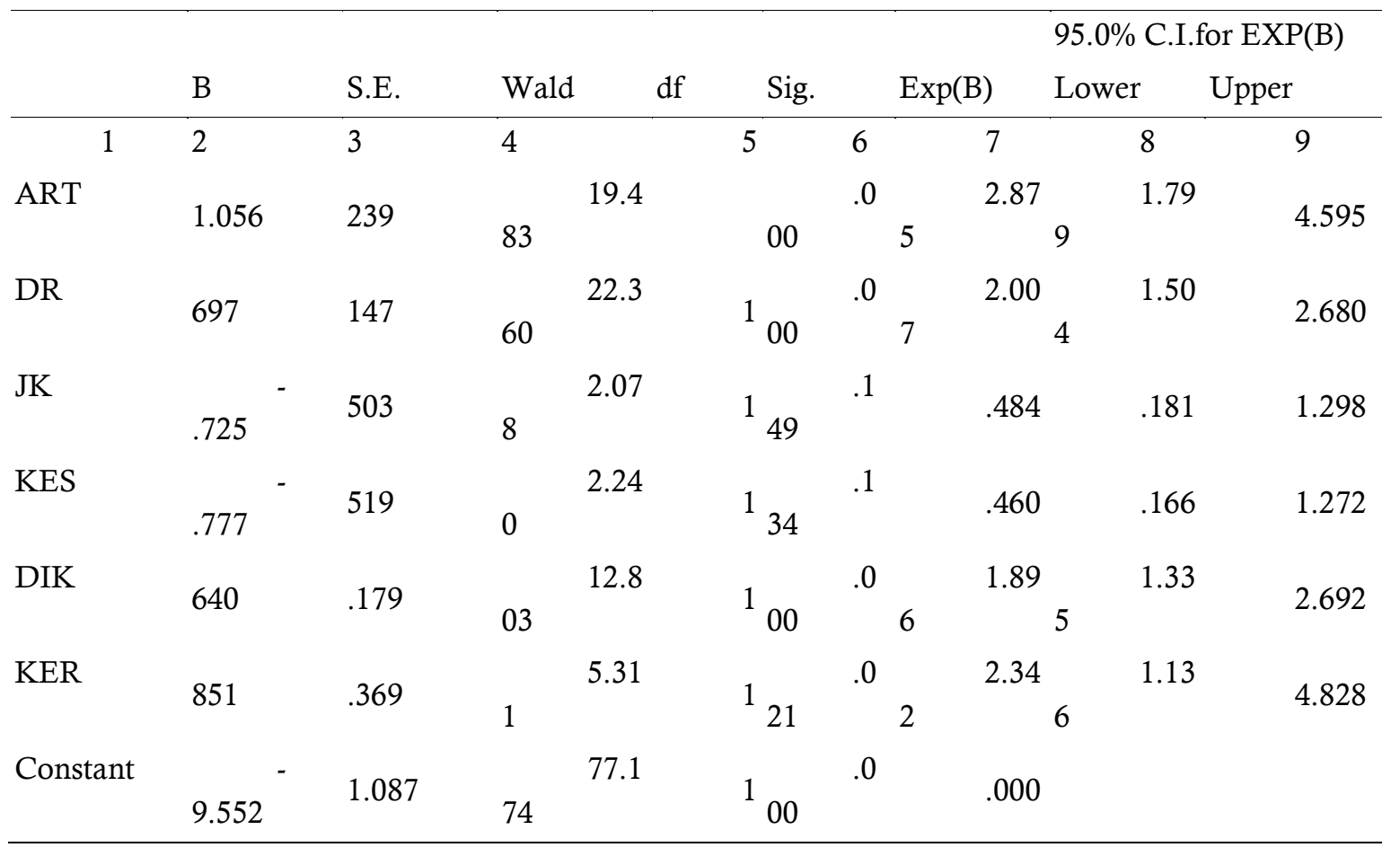

Penafsiran Model dan Rasio Kecenderungan, penafsiran dalam model logit sedikit berbeda dengan regresi biasa, karena penafsiran analisis logistik adalah seberapa besar peluang terjadinya peristiwa (variabel tak bebas 
sukses bernilai satu) apabila diketahui nilai variabel bebasnya. Hasil persamaan logit seperti;

$$
\begin{gathered}
\mathrm{L}(\mathrm{Y})=\ln \left(\frac{p_{Y}}{1-p_{Y}}\right)=-9,552+1,056 \mathrm{ART}+0,697 \mathrm{DR}-0,725 \mathrm{JK}-0,777 \mathrm{KES}+ \\
0,640 \mathrm{DIK}+0,851 \mathrm{KER}
\end{gathered}
$$

maka besarnya peluang terjadinya peristiwa $\left(\mathrm{p}_{\mathrm{y}}\right)$

untuk variabel bebasnya adalah:

$$
p_{y}=\frac{1}{1+e^{-(-9,552+1,056 \mathrm{ART}+0,697 \mathrm{DR}-0,725 \mathrm{JK}-0,777 \mathrm{KES}+0,640 \mathrm{DIK}+0,851 \mathrm{KER})}}
$$

Angka ketergantungan (variabel

Model tersebut dapat memberikan prediksi probalitas suatu rumah tangga akan miskin dengan karakteristik tertentu. Jika suatu rumah tanggamempunyai karakteristik jumlah anggota rumah tangga satu orang (berarti angka ketergantungan sama dengan nol), kepala rumah tangga tidak mengalami keluhan kesehatan, dengan pendidikan minimal SLTA dan bekerja di sektor jasa, maka probabilitas rumah tangga tersebut miskin adalah sebesar 0,04 persen atau probabilitas rumah tangga tersebut tidak miskin adalah sebesar 99,96 persen.

Apabila karakteristik rumah tangganya adalahjumlah anggota rumah tangga7 orang, dengan angka ketergantungan/DR sama dengan 6, kepala rumah tangga mengalami keluhan kesehatan dan terganggu, dengan pendidikan hanya lulus SD atau sederajat dan bekerja di sektor pertanian, maka probabilitas rumah tangga tersebut miskin adalah sebesar 96,41 persen atau probabilitas rumah tangga tersebut tidak miskin hanya adalah sebesar 3,59 persen.

Selajutnya model logistik juga digunakan untuk analisis rasio kecenderungan (odds ratio) dari suatu variabel bebas tertentu. Interpretasi nilai odds ratio seperti pada Tabel 5.7selengkapnya adalah sebagai berikut:

Jumlah anggota rumah tangga (variabel kontinyu). Nilai odd ratio sebesar 2,875 menunjukkan bahwa setiap penambahan satu anggota rumah tangga akan mengakibatkan resiko rumah tangga menjadi miskin sebesar $\mathrm{e}^{(1 \times}$

1,056) (= 2,875) kali lebih besar dibandingkan sebelumnya. kontinyu), merupakan merupakan variabel yang paling besar pengaruhnya terhadap kemiskinan rumah tangga. Hal ini terlihat dari angka odd ratio dari variabel angka ketergantungan yang sebesar 2,007, yang berarti bahwa setiap penambahan satu angka ketergantungan (misal dari 0,5 menjadi 1,5) akan mengakibatkan resiko rumah tangga menjadi miskin sebesar $\mathrm{e}^{(1 \times 0,697)}$ atau sama dengan 2,007 kali lebih besar dibandingkan sebelumnya. Sebagai contoh rumah tangga yang tadinya hanya suami, istri, dan satu anak bayi, kemudian bertambah dua anak berumur kurang dari 15 tahun, maka ia akan beresiko menjadi miskin sebesar 2,007 kali dibandingkan sebelum bertambah dua anak. Hubungan antara tingkat pendidikan kepala rumah tangga dan kemiskinan rumah tangga adalah positif. Hal ini berarti bahwa suatu rumah tangga yang tingkat pendidikan kepala rumah tanggamakin rendah maka kecenderungan rumah tangga untuk menjadi miskin akan semakin besar. Kecenderungan rumah tangga menjadi miskin dengan tingkat pendidikan satu tingkat atau satu jenjang yang lebih rendah adalah sebesar 1,896 kali dibandingkan dengan rumah tangga yang pendidikan kepala rumah tangganya satu tingkat atau satu jenjang lebih tinggi. Hubungan antara sektor pekerjaan/lapangan usaha kepala rumah tangga dan kemiskinan rumah tangga adalah positif. Hal ini berarti bahwa suatu rumah tangga yang kepala rumah tangganya bekerja di sektor primer (terutama pertanian), kecenderungan untuk menjadi miskin akan semakin besar dibandingkan dengan rumah tangga yang sektor pekerjaannya non primer (sekunder atau tersier). Kecenderungan rumah tangga menjadi miskin 
dengan sektor pekerjaan primer adalah sebesar 2,342kali dibandingkan dengan rumah tangga yang pekerjaan kepala rumah tangganya bekerja di sektor non primer (misalnya industri, perdagangan, atau jasa).

Dari hasil regresi logistik dengan metode stepwise hanya menghasilkan empat variabel yang signifikan. Sedangkan dua variabel yaitu jenis kelamin kepala rumah tanggadan keluhan kesehatan kepala rumah tangga tereliminir oleh proses. Dalam analisis kemiskinan lanjutan, nampaknya variabel jenis kelamin dan keluhan kesehatan kepala rumah tangga tidak dapat ditinggalkan, karena berdasarkan hasil logistik nilai signifikansinya tidak jauh menyimpang dari toleransi, yaitu untuk variabel jenis kelamin kepala rumah tangga tingkat signifikansinya sebesar 0,149 dan variabel keluhan kesehatan kepala rumah tangga tingkat signifikansinya sebesar 0,134, yang berarti masih signifikan pada tingkat 15 persen.

Hal ini dimungkinkan karena keterbatasan sampel rumah tangga terutama yang dikepalai oleh perempuan. Fenomena masih terjadinya diskriminasi terhadap perempuan seperti dalam bidang pendidikan, pekerjaan, dan bidang lainnya sehingga kemampuan perempuan pada umumnya dianggap lebih rendah daripada laki-laki merupakan suatu hal yang perlu dicermati bahwa jenis kelamin berpengaruh terhadap kegiatan maupun kondisi sosial ekonomi masyarakat.

\section{SIMPULAN}

Berdasarkan hasil pembahasan terhadap kemiskinan rumah tangga di Kabupaten Semarang dengan menggunakan data Survei Sosial Ekonomi Nasional 2013, dapat diidentifikasi faktor-faktor yang mempengaruhi kemiskinan rumah tangga dengan kesimpulkan sebagai berikut:

Faktor-faktor yang signifikan mempengaruhi kemiskinan rumah tangga di Kabupaten Semarang (dengan pengaruh dari yang paling besar) adalahangka ketergantungan, jumlah anggota rumah tangga, tingkat pendidikan kepala rumah tangga, dan sektor pekerjaan kepala rumah tangga. Variabelvariabel tersebut berpengaruh secara positif.

Rumah tangga dengan karakteristik jumlah anggota rumah tangga lebih dari 4 orang, angka ketergantungan di atas 100 persen, kepala rumah tangga dengan pendidikan paling tinggi SLTP dan bekerja di sektor pertanian, maka probabilitas rumah tangga tersebut miskin adalah lebih besar. Sebaliknya untuk kondisi rumah tangga yang jumlah anggota rumah tangga lebih kecil dari 4 orang, angka ketergantungan di bawah 100 persen, kepala rumah tangga dengan pendidikan minimal SLTA dan bekerja di sektor non primer (misal jasa), maka probabilitas rumah tangga tersebut miskin adalah lebih kecil. Hal ini menunjukkan bahwa seluruh variabel bebas tersebut berpengaruh signifikan terhadap kemiskinan.Variabel jenis kelamin kepala rumah tanggadan keluhan kesehatan kepala rumah tangga tidak signifikan mempengaruhi kemiskinan rumah tangga pada level 5 persen, tetapi signifikan pada level 15persen, oleh karena itu dalam penelitian atau analisis yang lain variabel ini tetap harus dipertimbangkan.Variabel-variabel tersebut berpengaruh secara negatif. Terdapat beberapa faktor yang secara nyata mempengaruhi kemiskinan rumah tangga, untuk itu disarankan: Penduduk miskin diperlakukan sebagai aktor utama dalam perang melawan kemiskinan, sedangkan peran pemerintah baik pusat maupun daerah sebagai fasilitator dan katalisator serta memberikan dukungan terhadap aktor utama, Program pengentasan kemiskinan harus benarbenar menyentuh akar permasalahan agar program tersebut hasilnyta dapat dirasakan secara nyata. Oleh karena itu perlu diketahui faktor apa saja yang secara nyata mempengaruhi kemiskinan rumah tangga di Kabupaten Semarang. Strategi dan kebijakan penanggulangan kemiskinan dilaksanakan dengan terencana, terpadu, sistematis, dan berkesinambungan melalui pembagian peran, dan didukung oleh kelembagaan, penganggaran, pengawasan dan pengendalian.

Prioritas program yang dapat mendorong rumah tangga miskin melakukan investasi SDM (melalui pendidikan dan pelatihan, kesehatan 
serta gizi) sehingga dalam jangka panjang dapat memutuskan rantai kemiskinan antar generasi.

Penelitian lebih lanjut mengenai kemiskinan rumah tangga perlu dilakukan dengan cakupan yang lebih luas (kalau perlu sensus secara bertahap), untuk memperoleh variabel-variabel lain yang belum tercakup dalam penelitian ini antara lain faktor non ekonomi; siapa, dimana, apa yang dibutuhkan, dan bagaimana kondisi atau karakteristik rumah tangga miskin.

\section{DAFTAR PUSTAKA}

Arsyad, Lincolin. 1999. Ekonomi Pembangunan. Yogyakarta: Yayasan Penerbit STIE YKPN Yogyakarta.

Badan Pusat Statistik (BPS). 2000. Metodologi Penentuan Rumah Tangga Miskin 2000. Jakarta: BPS

Badan Pusat Statistik (BPS). 2002. Metodologi dan Profil Kemiskinan 2002. Jakarta: BPS.

Badan Pusat Statistik (BPS). 2004a. Penduduk Fakir Miskin 2004. Jakarta: BPS

Badan Pusat Statistik (BPS). 2004b. Survei Sosial Ekonomi Nasional 2004, Pedoman Pencacah KOR. Jakarta: BPS.

Badan Pusat Statistik (BPS). 2015. Jawa Tengah dalam Angka. Jakarta: BPS.

Budiarti, Winih. 2004. Analisis Karakteristik Demografi, Sosial dan Ekonomi Penduduk Miskin di DKI Jakarta Tahun 2002. Jakarta: STIS.

Cess. 2003. Program Anti Kemiskinan Di Indonesia, Pemetaan Informasi dan Kegiatan. Jakarta: Cess.

Diliana, Fransiska Bonita. 2005. Perbandingan Faktor-faktor yang Mempengaruhi Pendapatan Rumah Tangga di Kabupaten Klaten dan Kabupaten Magelang Tahun 2003. Jakarta: STIS.

Hentschel, J., Lanjouw, J.O., Lanjouw, P., and Poggi, J., 2000. Combining Census and Survey Data to Trace the Spatial Dimensions of Poverty: A Case Study of Ecuador.World Bank Economic Review14(1)147-165.

Makmun. 2003. Gambaran Kemiskinan dan Action Plan Penanganannya. Kajian Ekonomi Dan Keuangan, Vol. 7, No. 2 Juni 2003.

Mathiassen A. and Hansen D.R.,2007, Predicting poverty for Mozambique 2000 to 2005 How robust are the models?, Statistics
Norway/Division for Development Cooperation, Documents 2007/4.

Nachrowi, Nachrowi Djalal dan Hardius Usman. 2002. Penggunaan Teknik Ekonometri:Pendekatan Populer dan Praktis Dilengkapi dengan Teknik Analisis Data dengan Menggunakan Paket Program SPSS. Jakarta: PT. Raja Grafindo Persada.

Nasir, Muhammad, dkk. 2008. "Analisis FaktorFaktor yang Mempengaruhi Kemiskinan Rumah Tangga di Kabupaten Purworejo". Eksekutif Vol. 5 No. 2, Agustus 2008

Sahdan, Gregorius. 2005.Menanggulangi Kemiskinan Desa. Artikel - Ekonomi Rakyat dan Kemiskinan - Maret 2005.

Samijan. 2004. Peubah-peubah yang Mempengaruhi Kemiskinan Rumah tangga di Wilayah Perkotaan dan Perdesaan di Kepulauan Papua Tahun 2003. Jakarta: STIS.

Santoso, Singgih. 2002. Buku Latihan SPSS Statistik Parametrik.Jakarta: PT. Elex Media Komputindo.

Suryawati Chriswardani, 2005.Memahami Kemiskinan secara Multidimensional, JMPK Vol. 08/No.03/September/2005:121-129

Sudjatmiko

Heru.http://www.harianjogja.com/baca/2016/ 06/08/kemiskinan-di-jateng-ini-4-strategitkpkd-jateng-tekan-angka-kemiskinan

World Bank Institute. 2002. Dasar-dasar Analisis Kemiskinan. (Terjemahan Ali Said dan Aryago Mulia). Jakarta: BPS dan World Bank Institute. 
LAMPIRAN

Lampiran 1. Daftar Sampel Rumah Tangga dan Variabel Analisisnya

\begin{tabular}{|c|c|c|c|c|c|c|c|c|}
\hline NO & Kemiskinan Ruta & ART & $\mathrm{DR}$ & Kelmp_DR & JK & KES & DIK & KER \\
\hline 1 & 0 & 3 & 1,50 & 4 & 0 & 1 & 2 & 0 \\
\hline 2 & 0 & 3 & 0,50 & 2 & 0 & 0 & 4 & 1 \\
\hline 3 & 0 & 3 & 1,50 & 4 & 0 & 0 & 2 & 0 \\
\hline 4 & 0 & 1 & 0,00 & 1 & 0 & 0 & 5 & 1 \\
\hline 5 & 0 & 3 & 0,25 & 1 & 0 & 0 & 5 & 1 \\
\hline 6 & 0 & 3 & 0,25 & 1 & 0 & 0 & 4 & 1 \\
\hline 7 & 0 & 2 & 0,33 & 1 & 0 & 0 & 4 & 0 \\
\hline 8 & 0 & 3 & 0,25 & 1 & 0 & 0 & 5 & 0 \\
\hline 9 & 0 & 1 & 0,00 & 1 & 0 & 0 & 5 & 1 \\
\hline 10 & 0 & 2 & 0,33 & 1 & 0 & 1 & 4 & 0 \\
\hline 11 & 0 & 3 & 0,00 & 1 & 0 & 0 & 5 & 1 \\
\hline 12 & 0 & 2 & 0,00 & 1 & 0 & 0 & 1 & 0 \\
\hline 13 & 0 & 2 & 0,00 & 1 & 0 & 0 & 2 & 0 \\
\hline 14 & 0 & 3 & 0,25 & 1 & 0 & 1 & 4 & 0 \\
\hline 15 & 0 & 2 & 0,00 & 1 & 0 & 0 & 4 & 0 \\
\hline 16 & 0 & 1 & 0,00 & 1 & 1 & 0 & 5 & 0 \\
\hline 17 & 0 & 3 & 0,25 & 1 & 0 & 1 & 4 & 1 \\
\hline 18 & 0 & 2 & 0,33 & 1 & 0 & 0 & 2 & 0 \\
\hline 19 & 0 & 1 & 0,00 & 1 & 0 & 1 & 1 & 0 \\
\hline 20 & 0 & 1 & 0,00 & 1 & 1 & 0 & 2 & 0 \\
\hline 21 & 0 & 3 & 0,25 & 1 & 0 & 0 & 2 & 1 \\
\hline 22 & 0 & 3 & 0,33 & 1 & 0 & 0 & 2 & 1 \\
\hline 23 & 0 & 1 & 0,00 & 1 & 0 & 0 & 2 & 0 \\
\hline 24 & 0 & 1 & 0,00 & 1 & 0 & 0 & 2 & 0 \\
\hline 25 & 0 & 2 & 0,00 & 1 & 0 & 0 & 4 & 1 \\
\hline 26 & 0 & 1 & 0,00 & 1 & 0 & 0 & 5 & 0 \\
\hline 27 & 0 & 2 & 0,00 & 1 & 0 & 0 & 4 & 0 \\
\hline 28 & 0 & 2 & 0,33 & 1 & 0 & 0 & 3 & 0 \\
\hline 29 & 0 & 1 & 0,00 & 1 & 0 & 0 & 1 & 0 \\
\hline 30 & 0 & 1 & 0,00 & 1 & 1 & 1 & 1 & 1 \\
\hline 31 & 0 & 2 & 0,00 & 1 & 0 & 0 & 1 & 0 \\
\hline 32 & 0 & 3 & 0,00 & 1 & 1 & 0 & 1 & 1 \\
\hline 33 & 0 & 2 & 0,00 & 1 & 0 & 0 & 2 & 0 \\
\hline 34 & 0 & 3 & 0,25 & 1 & 0 & 0 & 1 & 0 \\
\hline 35 & 0 & 1 & 0,00 & 1 & 0 & 0 & 3 & 0 \\
\hline 36 & 0 & 1 & 0,00 & 1 & 0 & 0 & 2 & 0 \\
\hline 37 & 0 & 1 & 0,00 & 1 & 1 & 0 & 4 & 0 \\
\hline 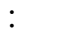 & & & & & & & & \\
\hline 790 & 0 & 3 & 1,50 & 4 & 0 & 1 & 5 & 1 \\
\hline 791 & 0 & 1 & 9,00 & 4 & 0 & 1 & 5 & 1 \\
\hline
\end{tabular}


Lampiran 2 : Hasil Penghitungan Regresi Logistik

\section{Logistic Regression Case Processing Summary}

\begin{tabular}{llll}
\hline Unweighted Cases $^{\mathrm{a}}$ & $\mathrm{N}$ & Percent \\
\hline Selected Cases & Included in Analysis & 791 & 100.0 \\
& Missing Cases & 0 & .0 \\
& Total & 791 & 100.0 \\
Unselected Cases & & 0 & .0 \\
Total & & 791 & 100.0
\end{tabular}

a. If weight is in effect, see classification table for the total number of cases.

Dependent Variable Encoding

\begin{tabular}{ll}
\hline Original Value & Internal Value \\
Tidak miskin & 0 \\
Miskin & 1 \\
\hline
\end{tabular}

Block 0: Beginning BlockIteration History ${ }^{\mathrm{a}, \mathrm{b}, \mathrm{c}}$

\begin{tabular}{llll}
\hline & & Coefficients \\
Iteration & & -2 Log likelihood & Constant \\
\hline Step 0 & 1 & 420.475 & -1.757 \\
& 2 & 366.258 & -2.446 \\
& 3 & 362.080 & -2.706 \\
& 4 & 362.028 & -2.739 \\
& 5 & 362.028 & -2.739 \\
\hline
\end{tabular}

a. Constant is included in the model.

b. Initial -2 Log Likelihood: 362.028

c. Estimation terminated at iteration number 5 because parameter estimates changed by less than .001 .

\section{Classification Table ${ }^{\mathrm{a}, \mathrm{b}}$}

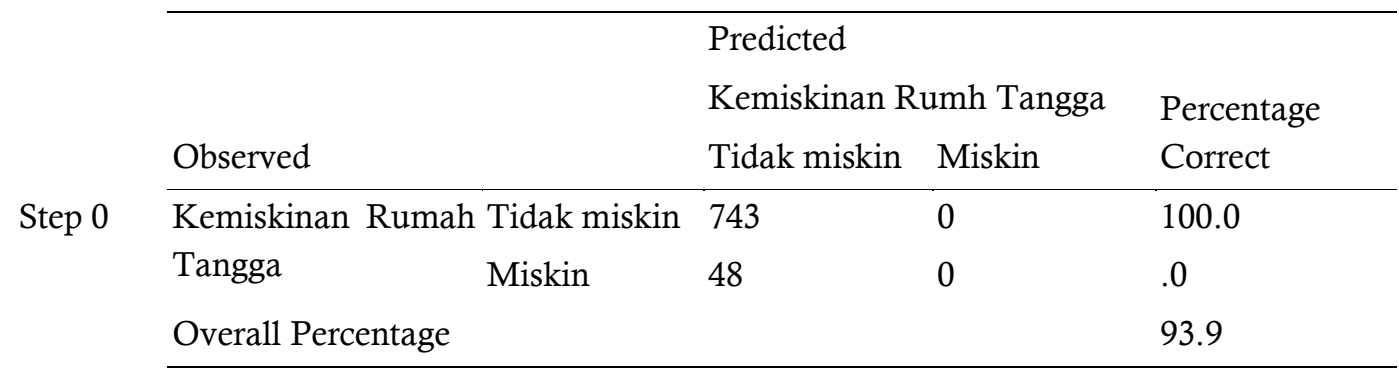

a. Constant is included in the model.

b. The cut value is .500 
Block 0: Beginning BlockIteration History ${ }^{\mathrm{a}, \mathrm{b}, \mathrm{c}}$

\begin{tabular}{llll}
\hline & & & Coefficients \\
Iteration & & -2 Log likelihood & Constant \\
\hline Step 0 & 1 & 420.475 & -1.757 \\
& 2 & 366.258 & -2.446 \\
& 3 & 362.080 & -2.706 \\
& 4 & 362.028 & -2.739 \\
& 5 & 362.028 & -2.739 \\
\hline
\end{tabular}

a. Constant is included in the model.

b. Initial -2 Log Likelihood: 362.028

Variables in the Equation

\begin{tabular}{|c|c|c|c|c|c|c|c|}
\hline & & B & S.E. & Wald & $\mathrm{df}$ & Sig. & $\operatorname{Exp}(B)$ \\
\hline Step 0 & Constant & -2.739 & .149 & 338.372 & 1 & .000 & .065 \\
\hline
\end{tabular}

Variables not in the Equation

\begin{tabular}{|c|c|c|c|c|c|}
\hline & & & Score & $\mathrm{df}$ & Sig. \\
\hline \multirow[t]{7}{*}{ Step 0} & \multirow[t]{6}{*}{ Variables } & ART & 19.362 & 1 & .000 \\
\hline & & DR & 25.876 & 1 & .000 \\
\hline & & JK & .259 & 1 & .611 \\
\hline & & KES & .856 & 1 & .355 \\
\hline & & DIK & 16.757 & 1 & .000 \\
\hline & & KER & 14.347 & 1 & .000 \\
\hline & \multicolumn{2}{|c|}{ Overall Statistics } & 70.506 & 6 & .000 \\
\hline
\end{tabular}


Block 1: Method = EnterIteration History ${ }^{\mathrm{a}, \mathrm{b}, \mathrm{c}, \mathrm{d}}$

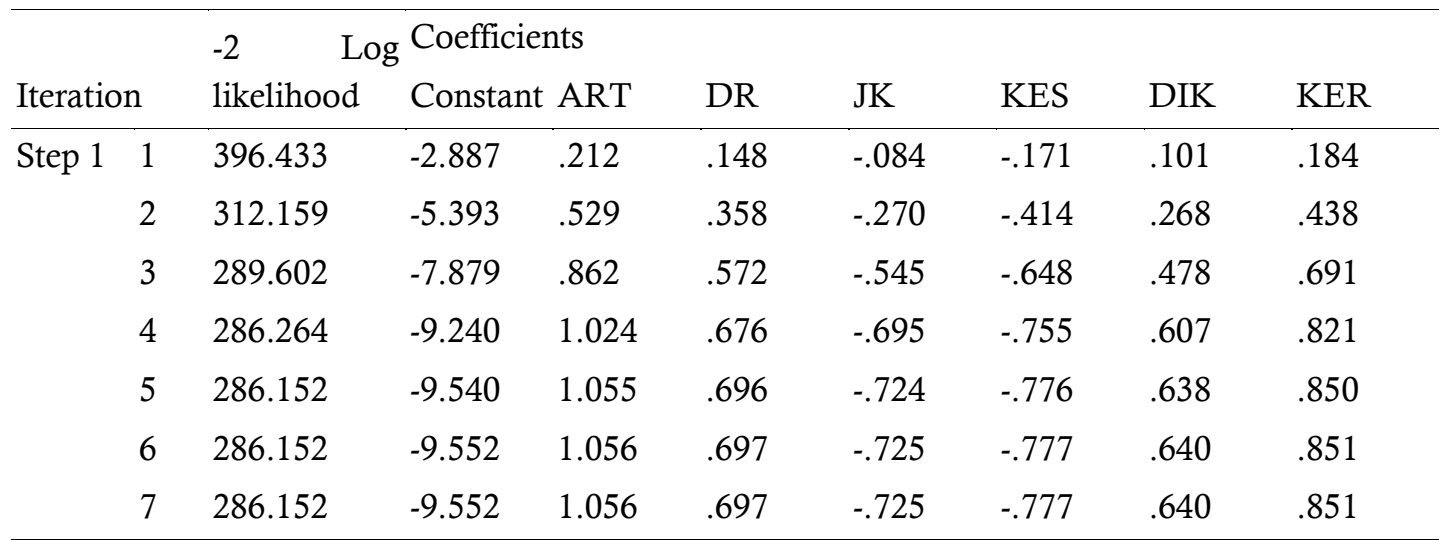

a. Method: Enter

b. Constant is included in the model.

c. Initial -2 Log Likelihood: 362.028

d. Estimation terminated at iteration number 7 because parameter estimates changed by less than .001 .

Omnibus Tests of Model Coefficients

\begin{tabular}{lllll}
\hline & & Chi-square & df & Sig. \\
\hline Step 1 & Step & 75.876 & 6 & .000 \\
& Block & 75.876 & 6 & .000 \\
& Model & 75.876 & 6 & .000 \\
\hline
\end{tabular}

Model Summary

\begin{tabular}{lllll}
\hline Step & $-2 \log$ likelihood & $\begin{array}{l}\text { Cox \& } \\
\text { Square }\end{array}$ & $\begin{array}{c}\text { Snell } \\
\text { R Nagelkerke } \\
\text { Square }\end{array}$ & R \\
\hline 1 & $286.152^{\mathrm{a}}$ & .091 & .249 \\
\hline
\end{tabular}

a. Estimation terminated at iteration number 7 because parameter estimates changed by less than .001 .

Hosmer and Lemeshow Test

\begin{tabular}{llll}
\hline Step & Chi-square & $\mathrm{df}$ & Sig. \\
\hline 1 & 21.232 & 8 & .007 \\
\hline
\end{tabular}

